\title{
Imaging bacteria with radiolabelled quinolones, cephalosporins and siderophores for imaging infection: a systematic review
}

\author{
S. Auletta ${ }^{1} \cdot$ F. Galli $^{1} \cdot$ C. Lauri $^{1} \cdot$ D. Martinelli ${ }^{2} \cdot$ I. Santino $^{2} \cdot$ Alberto Signore $^{1}$
}

Received: 7 April 2016/Accepted: 17 May 2016/Published online: 18 July 2016

(c) The Author(s) 2016. This article is published with open access at Springerlink.com

\begin{abstract}
Bacterial infections are still one of the main causes of patient morbidity and mortality worldwide. Nowadays, many imaging techniques, like computed tomography or magnetic resonance imaging, are used to identify inflammatory processes, but, although they recognize anatomical modifications, they cannot easily distinguish bacterial infective foci from non bacterial infections. In nuclear medicine, many efforts have been made to develop specific radiopharmaceuticals to discriminate infection from sterile inflammation. Several compounds (antimicrobial peptides, leukocytes, cytokines, antibiotics...) have been radiolabelled and tested in vitro and in vivo, but none proved to be highly specific for bacteria. Indeed factors, including the number and strain of bacteria, the infection site, and the host condition may affect the specificity of tested radiopharmaceuticals. Ciprofloxacin has been proposed and intensively studied because of its easy radiolabelling method, broad spectrum, and low cost, but at the same time it presents some problems such as low stability or the risk of antibiotic resistance. Therefore, in the present review studies with ciprofloxacin and other radiolabelled antibiotics as possible substitutes of ciprofloxacin are reported. Among them we can distinguish different classes, such as cephalosporins, fluoroquinolones, inhibitors of nucleic acid synthesis,
\end{abstract}

Alberto Signore

alberto.signore@uniroma1.it

1 Nuclear Medicine Unit, Department of Medical-Surgical Sciences and of Translational Medicine, Faculty of Medicine and Psychology, St. Andrea Hospital, "Sapienza" University of Rome, Via di Grottarossa 1035, 00189 Rome, Italy

2 Microbiology Unit, Department of Clinical and Molecular Medicine, "Sapienza" University of Rome, Rome, Italy inhibitors of bacterial cell wall synthesis and inhibitors of protein synthesis; then also others, like siderophores or maltodextrin-based probes, have been discussed as bacterial infection imaging agents. A systematic analysis was performed to report the main characteristics and differences of each antibiotic to provide an overview about the state of the art of imaging infection with radiolabelled antibiotics.

Keywords Antibiotics - Infection - Bacteria · Radiolabelled antibiotic $\cdot$ Molecular imaging

\section{Introduction}

Bacterial infections are still one of the main causes of mortality and morbidity worldwide. This is also because of the lack of specific agents to detect infective foci or to discriminate infection from sterile inflammation. Diagnostic radiological imaging offers various techniques to identify inflammatory processes, but they allow to detect only anatomical changes of the infection and are not always able to discriminate infections from normal postsurgical changes in the early stages [1]. On the other hand, nuclear medicine offers many radiopharmaceuticals that can detect physiological and biochemical changes at the early stages of infection. They include radiolabelled antimicrobial peptides, antibiotics, leukocytes, but also immunoglobulins and cytokines labelled with gamma- or positron-emitting isotopes $\left({ }^{18} \mathrm{~F},{ }^{99 \mathrm{~m}} \mathrm{Tc},{ }^{111} \mathrm{In},{ }^{67} \mathrm{Ga}\right.$ etc....) [2-5]. In addition, the use of radiopharmaceuticals able to detect $\mathrm{T}$ lymphocyte infiltration in autoimmune or inflammatory bowel diseases (IBD) has been proposed as an alternative approach [6]. Unfortunately none of these are specific enough for bacteria thus allowing to discriminate 
infection from sterile inflammation, in spite of high sensibility. This depends on the nature of the radiopharmaceutical, its biodistribution and binding properties but also on the type of microorganism, the kind of infection, the infection site and the host conditions. Another unsolved issue is the minimum number of micro-organisms necessary to perform a reliable diagnosis, which has already been discussed [7]. In clinical nuclear medicine, among the many ${ }^{99 \mathrm{~m}} \mathrm{Tc}$-labelled compounds, antibiotics looked the most promising to image infection. They are divided in several classes, based on their mechanism of action. The first radiolabelled antibiotic, used as radiopharmaceutical, was ${ }^{99 \mathrm{~m}} \mathrm{Tc}$-ciprofloxacin, that pioneered the use of radiopharmaceuticals for bacterial imaging. Nevertheless, it appeared soon clear that the task of imaging bacteria is very complex with many problems to be solved [7-9].

In this article, the use of radiolabelled ciprofloxacin is reviewed together with other "infection-specific" radiolabelled antibiotics, developed with the aim to discover tools with better properties than ${ }^{99 \mathrm{~m}} \mathrm{Tc}$-ciprofloxacin. These antibiotics are divided into several categories, according to their mechanisms of action.

\section{Bacteria, biofilm and antibiotic mechanisms of action}

Planktonic bacteria are free-living bacteria, which are generally treatable with antibiotics but when they adhere to a surface develop a biofilm. A commonly used definition of a biofilm is a "microbially derived sessile community characterized by cells that are irreversibly attached to a substratum, interface or to each other, are embedded in a matrix of extracellular polymeric substances that they have produced, and exhibit an altered phenotype with respect to growth rate and gene transcription" [10]. Biofilm embedded bacteria represent a serious clinical problem in medicine, because their infections are notoriously difficult to treat due to extreme resistance to antibiotics.

Antibiotics are drugs of natural or synthetic origin that have the capacity to kill (bactericidal drugs) or inhibit (bacteriostatic drugs) the cell growth. Most bactericidal antimicrobials are: cephalosporins, carbapenems, glycopeptides, fluoroquinolones, polymyxins that inhibit DNA synthesis, RNA synthesis, cell wall synthesis, or bacterial protein synthesis.

Fluoroquinolones (FQs) are bactericidal antibiotics effective for both Gram-negative and Gram-positive bacteria and ciprofloxacin is the most widely used antimicrobial agent among FQs. The action of ciprofloxacin results from inhibition of the enzymes topoisomerase II (DNA gyrase, gyrA and B) and topoisomerase IV (grlA and B), which are required for bacterial DNA replication, transcription, repair, strand super coiling repair, and recombination. Resistance to FQs in bacteria is mainly mediated by alterations in DNA gyrase and topoisomerase IV with specific amino acid substitutions in the "quinolone-resistance determining region" (QRDR) in gyrA and B subunits of DNA gyrase and parC and parE subunits of topoisomerase IV. Other common mechanisms are reduced permeability/increased efflux of ciprofloxacin across bacterial membranes, and plasmids that protect cells from the lethal effects of FQs $[11,12,15]$.

Toxic effects of FQs on humans have been attributed to their interactions with different receptor complexes, such as blockade of the GABAa receptor complex within the central nervous system, leading to excitotoxic type effects and oxidative stress.

The cephalosporins are the largest family of $\beta$-lactam antibiotics. They are bactericidal agents and have the same mode of action as other beta-lactam antibiotics (such as penicillin). Cephalosporins disrupt the synthesis of the peptidoglycan layer of bacterial cell walls by binding to penicillin binding proteins (PBPs), causing the walls to break down and eventually the bacteria die. The three fundamental mechanisms of antimicrobial resistance are: enzymatic degradation of antibacterial drugs, changes in PBPs, and changes in membrane permeability to antibiotics. The most important mechanism of resistance to cephalosporins is destruction of beta-lactam rings by $\beta$ lactamase enzymes. Mutational changes in original PBPs or acquisition of different PBPs will lead to inability of the antibiotic to bind to the PBPs and inhibit cell wall synthesis. A change in the number or function of the general diffusion porin channels can reduce the permeability.

Since antimicrobial compounds act on processes that are unique to bacteria, it has been proposed that radiolabelled antibiotic should be able to distinguish microbial from non microbial inflammation, because of their specific binding to the causative agents.

\section{Ciprofloxacin}

${ }^{99 \mathrm{~m}} \mathrm{Tc}$-ciprofloxacin, also known as Infecton, was the first radiolabelled antibiotic tested in human to image infections [8]. In preclinical studies many different animal models have been used to prove ciprofloxacin specificity. In rats ${ }^{99 \mathrm{~m}} \mathrm{Tc}$-ciprofloxacin showed an excellent biodistribution with renal clearance, and targeting experiments showed a high sensitivity but low specificity. Ciprofloxacin was also conjugated with propylamine and then labelled with ${ }^{68} \mathrm{Ga}$, revealing to be a good bacteria-specific imaging agent in a S. aureus infected rat model [16-18].

Different results were obtained when ${ }^{99 \mathrm{~m}}$ Tc-ciprofloxacin was studied in mice and both high sensitivity and 
specificity for imaging infections were obtained [14, 19-22].

Controversial results were obtained using other animal models like rabbits, camelids, dogs or swines to evaluate the ability of ${ }^{99 \mathrm{~m}}$ Tc-ciprofloxacin to localize the infectious site, in severe acute pancreatitis, prosthetic joint infections or other suspected infections [23-26].

In clinical studies, it was more difficult to study the pharmacokinetics of ciprofloxacin in organs and tissues, particularly in the gastrointestinal tract, lungs and soft tissues.

Positron Emission Tomography (PET) could be a technique that allows a direct quantification of the antibiotic, when labelled with positron-emitting isotopes like ${ }^{18} \mathrm{~F}$. Indeed, two studies performed by Brunner et al. and Langer et al. [13, 27], using PET with ${ }^{18} \mathrm{~F}$-ciprofloxacin, showed opposite results in healthy volunteers and patients with suspected infections, respectively. In particular Langer and colleagues concluded that ${ }^{18} \mathrm{~F}$-ciprofloxacin is not a suitable and specific radiopharmaceutical for imaging infections.

Many other studies in patients have been performed using ${ }^{99 \mathrm{~m}}$ Tc-labelled ciprofloxacin. Most of them had concordant results about the labelling procedure using the kit formulated at St. Bartholomew's Hospital in London [28] and about the metabolism of the radiopharmaceutical, which was prevalently renal, with low level of hepatic uptake and no bone marrow, bone and gastrointestinal uptake. However, final results showed a high variability in terms of sensibility and specificity. These controversial and variable data may depend on the type and site of infections, strain of micro-organisms, presence of antibiotic therapy, lack of standardized imaging parameters and interpretation criteria, but also on the type of imaging modality (SPECT or planar scintigraphy) [29, 30]. Some authors have considered Infecton as a good bacterial infection imaging agent, particularly when SPECT images are acquired for the diagnosis of pulmonary or extrapulmonary tuberculosis, fever or unknown origin (FUO), osteomyelitis, hip or knee prosthesis, active spinal infections, abdominal or gastrointestinal and orthopaedic infections, despite of conflicting results based on the type of infection. Moreover, it allows to evaluate the presence of infection in immune-suppressed patients, when white blood cell (WBC) imaging was uncertain or to monitor and optimize the antimicrobial treatment. However, in addition to image analysis, a microbiological culture was often useful to confirm the presence and nature of the infection [8, 28, 31-44]. Other authors have considered ${ }^{99 \mathrm{~m}} \mathrm{Tc}$ ciprofloxacin as a potential imaging agent only for the diagnosis of orthopaedic infections, vertebral infections, osteoarticular tuberculosis and diabetic foot infections, in comparison to ${ }^{99} \mathrm{~m}$ Tc-WBC or immunoscintigraphy, showing excellent diagnostic accuracy [45-50]. By contrast, other studies, by Dumarey et al., De Winter et al., Sarda et al., Pucar et al., Appelboom et al. and Gemmel et al. [51-56], reported a low specificity but high sensitivity for Infecton imaging. These studies were performed in patients with different kind of infections and images were acquired and analyzed with different methods, but all concluded that ${ }^{99 \mathrm{~m}} \mathrm{Tc}$-ciprofloxacin is unable to discriminate bacterial infection from sterile inflammation.

Finally, Zhang et al. [57, 58] performed a study with ciprofloxacin dithiocarbamate labelled with $\left[{ }^{99 m} \mathrm{TcN}\right]^{2+}$ intermediate or $\left[{ }^{99 \mathrm{~m}} \mathrm{Tc}(\mathrm{CO})_{3}(\mathrm{H} 2 \mathrm{O})_{3}\right]^{+}$intermediate. These radiopharmaceuticals were tested in $S$. aureus infected mice to evaluate their biodistribution and their ability to distinguish septic and aseptic inflammation in comparison to ${ }^{99 \mathrm{~m}}$ Tc-ciprofloxacin. Experimental data showed that both new radiopharmaceuticals had a better target-to-non target $(T / \mathrm{NT})$ ratio than ${ }^{99 \mathrm{~m}} \mathrm{Tc}$-ciprofloxacin and they could be considered potential infection imaging agents.

\section{Fluoroquinolones}

The quinolones can be differentiated in several generations, which differ for broad-spectrum activity and pharmacokinetic properties like a rapid and complete absorption from gastrointestinal tract or oral administration [59, 60].

For example pefloxacin is a fluoroquinolone antibacterial agent, which has been investigated as a potential substitute for ciprofloxacin in the detection of bacterial infections. It was labelled with ${ }^{99 \mathrm{~m}} \mathrm{Tc}$, tested in mice infected with $E$. coli or injected with turpentine oil as sterile inflammation. Experimental data showed a main excretion through liver and intestine and a high retention in infectious foci than aseptic foci after $24 \mathrm{~h}$ from injection because of its specific binding to gyrase, confirmed by the $T / \mathrm{NT}$ ratio equal to 5.6 at $24 \mathrm{~h}$ post injection. Moreover pefloxacin had a rapid clearance, no accumulation in nontarget organs, no toxicity, low cost and a simple preparation, that makes it a good potential imaging agent [61].

The second generation of fluoroquinolones includes many compounds, more or less specific for bacterial infections. Amongst the most specific agents there are lomefloxacin and ofloxacin that were always studied in comparison to ciprofloxacin. The radiolabelling procedure with ${ }^{99 \mathrm{~m}} \mathrm{Tc}$ is easy, without any purification in comparison to ciprofloxacin and they have been tested in $S$. aureus infected rats compared to normal rats as control. The biodistribution studies, obtained by ex vivo $\gamma$-counting, revealed renal excretion and low uptake in the liver, that indicates few hydrolyzed products of ${ }^{99 \mathrm{~m}} \mathrm{Tc}$ for both antibiotics. T/NT ratio for lomefloxacin was higher than for ofloxacin, $\quad 6.5 \pm 0.5$ and $4.3 \pm 0.6$ respectively, 
suggesting that lomefloxacin might be a better imaging agent than ofloxacin [62]. The low specificity of ofloxacin has been confirmed in another study performed by Erfani et al. They labelled the antibiotic with ${ }^{99 \mathrm{~m}} \mathrm{Tc}$ and investigated the biodistribution in S. aureus infected mice. Also in this case authors found a renal and liver clearance and a $T /$ NT ratio equal to $2.02 \pm 0.12$ at $4 \mathrm{~h}$ after injection, a sign of poor specificity [63].

Two other poorly specific antibiotics are enrofloxacin and norfloxacin. The former was studied in comparison to ciprofloxacin by Siaens et al. It was radiolabelled with ${ }^{99 \mathrm{~m}} \mathrm{Tc}$ and injected in $S$. aureus treated rats. In this study the control rats were injected with turpentine oil, heat killed S. aureus or C. albicans. Results showed high renal uptake and no significant differences in the level of accumulation in the various inflamed muscles, indicating poor capacity to recognize infection from sterile inflammation [64]. Recently, ${ }^{99 \mathrm{~m}} \mathrm{Tc}$-enrofloxacin was also studied by Shahzad et al. [65], obtaining more or less the same results as previously published by others. Indeed, the radiolabelled compound always showed the same biodistribution in non target organs and no high uptake in the infected muscle versus control.

The other non specific antibiotic, norfloxacin, was also labelled with ${ }^{99 \mathrm{~m}} \mathrm{Tc}$ and its biodistribution evaluated in rats infected with $10^{7}-10^{8} \mathrm{CFU}$ of $S$. aureus, heat killed $S$. aureus and turpentine oil. ${ }^{99 \mathrm{~m}} \mathrm{Tc}$-norfloxacin has an excretion through the urinary system and the uptake in infected or non-infected muscles is not statistically different. Based on these data, it was concluded that norfloxacin cannot discriminate bacterial infection from sterile inflammation [66]. However, controversial results about norfloxacin were recently reported by Sazonova et al. [67] in rats where infection was induced with $10^{9} \mathrm{CFU}$ of $S$. aureus. Turpentine oil was used as control. Their results showed a mild uptake in the infected muscle as compared to inflamed one. The $T / \mathrm{NT}$ ratios were $2.87 \pm 0.80$ and $1 \pm 0.14$, respectively, for infected and inflamed muscle, confirming that this radiopharmaceutical requires further studies to improve its specificity. Another study, performed by Zhang et al. [68], tested norfloxacin dithiocarbamate as a potential imaging agent. It was labelled with ${ }^{99 \mathrm{~m}} \mathrm{Tc}$ and the biodistribution was studied in S. aureus infected mice, while sterile inflammation was induced using turpentine oil. Experimental data revealed a main hepato-biliary clearance and the $T / \mathrm{NT}$ ratios were 3.46 and 1.23 at $3 \mathrm{~h}$ post-injection, respectively for bacterial infection and sterile inflammation.

With third-generation FQs several properties were improved through modifications of the quinolone nucleus, such as anti-microbial activity and pharmacokinetics [69].

An antibiotic of this category, that could be a substitute of ciprofloxacin, is sparfloxacin. It was labelled with ${ }^{99 \mathrm{~m}} \mathrm{Tc}$ and then biodistribution was studied in rats where infection was induced using $10^{5}-10^{6} \mathrm{CFU}$ of $S$. aureus. Biodistribution studies showed a rapid clearance through the urinary system and a high accumulation in the infection site, more than ciprofloxacin. As early as $2 \mathrm{~h}$ post-injection, the $T / \mathrm{NT}$ ratio was $5.10 \pm 0.4$ for sparfloxacin and $3.60 \pm 0.4$ for ciprofloxacin [9]. It is also remarkable that in this study very few CFU of $S$. aureus were used (only $10^{5}-10^{6}$ ) as compared to the majority of published studies ranging from $10^{7}$ to $10^{10} \mathrm{CFU}$.

Levofloxacin is another third-generation fluoroquinolone. Shahzad et al. [70] labelled this antibiotic with ${ }^{99} \mathrm{~m}$ Tc using a freeze-dried kit. Biodistribution was studied in rabbit, infected with two different strains of bacteria $\left(3 \times 10^{8} \mathrm{CFU}\right.$ of $E$. coli and P. aeruginosa). Results showed kidneys as the main excretion route and T/NT ratios were 8.09 and 1.3 at $1 \mathrm{~h}$ post-injection, respectively in $P$. aeruginosa and $E$. coli infected muscles showing high variability depending on the kind of bacteria. Therefore ${ }^{99 \mathrm{~m}} \mathrm{Tc}$-levofloxacin could be a promising imaging agent for lung, sinus bone and skin infections, but it also needs other studies.

A fluoroquinolone derivative that is able to distinguish between septic and aseptic inflammation is rufloxacin. It was always labelled with ${ }^{99 \mathrm{~m}} \mathrm{Tc}$ and the biological distribution was evaluated in Albino mice after induction of infection with live $E$. coli and inflammation with turpentine oil or heat killed E. coli. Experimental data revealed an excretion through kidneys and urine and the uptake in the infected muscles were higher than heat-killed bacteria and turpentine oil inflamed muscle. The $T / \mathrm{NT}$ ratio was also higher compared to ciprofloxacin at all time points $(8.5 \pm 0.1$ vs $3.6 \pm 0.43 \mathrm{~h}$ post injection), demonstrating that rufloxacin could be a good infection imaging agent [71].

Another third generation fluoroquinolone is fleroxacin that it was studied as a PET radiopharmaceutical by Fischman et al. [72]. It was labelled with ${ }^{18} \mathrm{~F}$ and its pharmacokinetics was evaluated in healthy and $E$. coli infected rabbits, mice and rats. Biodistribution showed a main excretion through the intestinal tract, then liver and kidneys and no accumulation in the brain, especially in rats and mice. Unfortunately the accumulation in healthy and infected muscle of all animals was similar and ${ }^{18} \mathrm{~F}-$ fleroxacin was considered a poor PET imaging agent for bacteria.

Compared to previous generation, the fourth generation of FQs has the advantage to be resistant to spontaneous mutation, reducing the risk of antibiotic resistance. Their mechanism of action is the inhibition of DNA gyrase and topoisomerase IV, enhancing the Gram-positive spectrum, especially for ocular infections [73].

Sitafloxacin belongs to this generation. It was labelled with ${ }^{99 \mathrm{~m}} \mathrm{Tc}$ and biodistribution studies and scintigraphic 
images were evaluated, respectively in rats and rabbits, where infection was induced with $2 \times 10^{8} \mathrm{~S}$. aureus and inflammation induced with turpentine oil. Biodistribution confirmed the renal excretion also for this class of antibiotics with a high accumulation in infected muscles confirmed by in vivo images and $T / \mathrm{NT}$ ratio equal to $23.13 \pm 0.1$ at $2 \mathrm{~h}$ post injection. This $T / \mathrm{NT}$ ratio was the highest obtained with a radiolabelled antibiotic suggesting sitafloxacin as the best imaging agent for imaging infections caused by $S$. aureus [74]. It would be important to determine whether it can image also other strains of bacteria and whether the accumulation lasts over time.

Due to initial enthusiasm, sitafloxacin was chemically modified to sitafloxacin-dithiocarbamate, which is more stable, and then labelled with ${ }^{99 \mathrm{~m}} \mathrm{Tc}$ via a $\left[{ }^{99 \mathrm{~m}} \mathrm{TcN}\right]^{2+}$ core. Biodistribution studies and whole body images were performed in rats and rabbits, infected with $S$. aureus and turpentine oil and heat killed bacteria as controls. Experimental data showed a clearance through the kidneys and confirmed the high uptake in the infected muscle with living bacteria. The T/NT ratio was $7.40 \pm 1$ after $2 \mathrm{~h}$ from injection in the infectious foci, as compared to $1 \pm 1$ in the inflamed area, confirming this radiopharmaceutical as a very promising infection imaging agent [75].

${ }^{99}$ Tc-moxifloxacin could be considered another potential agent. It was studied in rats and rabbits after the induction of a septic inflammation with $E$. coli in the thigh muscle. On images it was possible to notice the infected site in a clear way, with a specific accumulation six times higher than in normal tissues [76].

Another antibiotic of this generation, specific for $S$. pneumoniae infection, is gemifloxacin. After labelling with ${ }^{99 \mathrm{~m}} \mathrm{Tc}$, it was tested in infected, inflamed and normal rats. Results showed an early uptake in the liver, followed by a renal clearance; the $T / \mathrm{NT}$ ratio between infected and normal muscle was maximum at $90 \mathrm{~min}$ and then decreased slightly [77]. Recently, another study, performed by Shahzad et al. [78], confirmed the specificity of ${ }^{99 \mathrm{~m}} \mathrm{Tc}$ gemifloxacin to localize respiratory tract infections. The radiopharmaceutical was studied in rabbits infected with three different strains of bacteria $\left(3 \times 10^{8} \mathrm{CFU}\right)$, including $K$. pneumoniae, S. typhi and $P$. aeruginosa. The maximum $T / \mathrm{NT}$ ratios were $8,8.87$ and 16.5 at $4 \mathrm{~h}$ post-injection, respectively for the three kinds of bacteria, confirming that ${ }^{99 \mathrm{~m}} \mathrm{Tc}$-gemifloxacin could be used as a bacterial imaging agent for lung infections.

Finally, another fluoroquinolone derivative has been proposed as ciprofloxacin's substitute by Moustapha et al. [79]. ${ }^{99 \mathrm{~m}} \mathrm{Tc}$-sarafloxacin was studied in vitro and in $S$. aureus infected mice, while as turpentine oil and heat killed bacteria were used to induce the aseptic inflammation. Experimental data revealed both renal and hepatic excretion with a low uptake in the infectious foci as compared to other quinolones of fourth generation. $T / \mathrm{NT}$ ratio in infected mice was $4.2 \pm 0.1$ at $2 \mathrm{~h}$ post injection, versus 3.4 and 3.3 for turpentine oil and heat killed bacteria.

\section{Cephalosporins}

Cephalosporins have also been radiolabelled for bacteria imaging in vivo. In 2013 El-Tawoosy et al. studied the best labelling condition of cephazolin with ${ }^{99 \mathrm{~m}} \mathrm{Tc}$ and its biological distribution in murine model, infected with $S$. aureus $\left(10^{7}-10^{8} \mathrm{CFU}\right)$ and turpentine oil as control. Results showed a good preparation and labelling of the product, a rapid distribution in mice with excretion through kidneys and intestine by $2 \mathrm{~h}$, and a infected/inflamed muscle ratio $(T / \mathrm{NT})$ equal to $4.60 \pm 0.21$ at $2 \mathrm{~h}$. However, since the highest ratio was $8.57 \pm 0.40$ at $30 \mathrm{~min}$, cephazolin is able to distinguish well the early stages of infection from sterile inflammation [80].

The second generation of cephalosporins has a spectrum of activity like the first generation antibiotics, but more active against Gram-negative bacteria, and includes antibiotics as cefuroxime axetil, whose bactericidal activity is the inhibition of cell wall synthesis through the binding to specific proteins. Its potential use as a radiopharmaceutical has been tested in rats with sterile and septic inflammation, caused by $10^{8} \mathrm{CFU}$ of $S$. aureus, in the Yurt Lambrecht's study. Results showed a rapid clearance by liver and kidney and a better retention in infectious areas than sterile inflamed areas because of its specific binding to gyrase enzymes. However, authors reported a low $T / \mathrm{NT}$

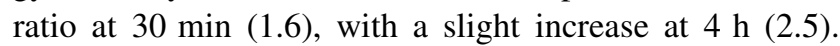
This suggests that ${ }^{99 \mathrm{~m}} \mathrm{Tc}$-cefuroxime acetil could be a promising infection imaging agent, but more studies are needed to confirm this hypothesis [81]. Cefuroxime is another second-generation cephalosporin antibiotic that was labelled and tested in a study performed by Chattopadhyay et al. [82]. After labelling with ${ }^{99 \mathrm{~m}} \mathrm{Tc}$, the compound was injected in rats infected with $10^{6}-10^{8} \mathrm{CFU}$ of E. coli bacteria in the left thigh. Experimental data showed a renal and hepatic excretion and a poor accumulation in the infection site, confirmed by the $T / \mathrm{NT}$ ratio (1.8) at $3 \mathrm{~h}$ from the injection. Therefore ${ }^{99 \mathrm{~m}} \mathrm{Tc}$-cefuroxime is not entirely able to distinguish bacterial infections. Third-generation cephalosporins are broad-spectrum antimicrobial agents used in many clinical situations. Among them, ceftizoxime has the best Gram-positive coverage [83]. Gomes Barreto et al. labelled it with ${ }^{99 \mathrm{~m}} \mathrm{Tc}$ for imaging of $E$. coli infection in rats' muscle compared to controls and animals bearing a sterile zymosan induced abscess. Experimental data underlined a maximum uptake in kidneys and a significant uptake in the septic muscle 
rather than in the sterile one. The uptake persisted up to $6 \mathrm{~h}$, as confirmed by a $T / \mathrm{NT}$ ratio of $3.24 \pm 1$ in the infection site, (1.65 \pm 0.23 in controls). On the basis of obtained data, ${ }^{99 \mathrm{~m}} \mathrm{Tc}$-ceftizoxime showed a moderate specificity that lead researchers to investigate its use in other models [84].

Costa et al. tested this radiolabelled antibiotic for the diagnosis of deep sternal wound infection. They used twenty rats divided into four groups, two controls and two with sternotomy and infection with $S$. aureus. Scintigraphic images revealed a higher levels of radioactivity, expressed as number of counts, in the region of interest of infected rats $(12,258.2 \pm 1729$ counts/10 min) than control counterparts $(4920.6 \pm 562.9)$ in different time points after injection. This result confirmed that ${ }^{99 \mathrm{~m}} \mathrm{Tc}$-ceftizoxime is a potential antimicrobial agent, which detects infection post sternotomy [85].

Also Teixeira et al. [86] used ${ }^{99 \mathrm{~m}}$ Tc-ceftizoxime for the diagnosis of suspected infections in titanium implants in rat model. Control rats received a sterile implant, while experimental group received an implant infected with $10^{9}$ $\mathrm{CFU}$ of $S$. aureus. Scintigraphic images showed higher uptake in infectious area in rats than in controls, expressed as the difference between groups, at $6.5 \mathrm{~h}$ post-injection. Despite these promising results in localizing infected implants, further studies are required to improve sensitivity and specificity of ${ }^{99 \mathrm{~m}} \mathrm{Tc}$-ceftizoxime.

Cefotaxime has a similar structure of ceftizoxime and was studied by Mirshojaei et al. [87] as a potential infection-imaging agent. After labelling with ${ }^{99 \mathrm{~m}} \mathrm{Tc}$, the biological distribution was performed in mice, infected with $10^{8} \mathrm{CFU}$ of $S$. aureus bacteria in the thigh muscle. Results showed a renal clearance, low hepato-biliary excretion and a poor accumulation in the infectious site with the maximum $T / \mathrm{NT}$ ratio at $1 \mathrm{~h}(2.89 \pm 0.58)$. Although a more rapid metabolic route, when compared to ${ }^{99 \mathrm{~m}} \mathrm{Tc}$-ciprofloxacin, ${ }^{99 \mathrm{~m}} \mathrm{Tc}$-cefotaxime requires more studies to demonstrate its specificity. Ilem-Ozdemir and coll. [88] labelled with ${ }^{99 \mathrm{~m}} \mathrm{Tc}$ the cefotaxime sodium. Then, they evaluated its biodistribution in rats, infected with $4 \times 10^{10} \mathrm{CFU}$ of $E$. coli or turpentine oil as control. Results showed a main renal excretion of radiopharmaceutical and a very poorly uptake in the infectious foci. Indeed the $T / \mathrm{NT}$ ratios were $3.77 \pm 2.38$ and $3.30 \pm 0.94$ at $1 \mathrm{~h}$ post injection.

Another third-generation cephalosporin, tested by various authors, is ceftriaxone. Also for this antibiotic, similar results were obtained and ${ }^{99 \mathrm{~m}} \mathrm{Tc}$-ceftriaxone could be able to distinguish sterile and septic inflammation. The first study, performed by Mostafa et al. in 2010, describes the labelling of ceftriaxone with ${ }^{99 \mathrm{~m}} \mathrm{Tc}$ and its biodistribution in a mouse model, infected with alive $E$. coli, heat killed bacteria and turpentine oil as controls. In this study the ability to differentiate between bacterial infection and sterile inflammation was demonstrated in vitro and confirmed in vivo. In mice, it showed renal excretion and a good retention at the infectious site because of its specific binding to bacteria. $T / \mathrm{NT}$ ratio for the living bacteria was $5.67 \pm 0.6$ at $4 \mathrm{~h}$ post injection as compared to the turpentine oil and heat killed $E$. coli ratios that were less of 2 [89]. The second study about ceftriaxone was published by Kaul et al. in 2012. The main purpose of the study was to assess the efficacy of ${ }^{99 \mathrm{~m}} \mathrm{Tc}$-ceftriaxone in vitro through bacterial binding assay with living and heat killed $S$. Aureus, but also in vivo in murine and rabbit models and in humans. Results confirmed the ability of the labelled antibiotic to discriminate between inflammation and infection: in fact scintigraphic images in rabbit showed a higher uptake in the infectious site than in the inflamed muscle at 4 and $24 \mathrm{~h}$, and also the $T / \mathrm{NT}$ ratio in mice with septic lesion was 4.5 at $24 \mathrm{~h}$ as compared to sterile inflammation that showed 1.4 at $24 \mathrm{~h}$. Clinical studies demonstrated that the radiolabelled antibiotic localizes acute bacterial infections, especially in bacterial osteomyelitis and could be used for diagnosis of other orthopaedic infections too [90]. A third study with ${ }^{99 \mathrm{~m}} \mathrm{Tc}$ ceftriaxone was performed by Fazli et al. [91], but it did not confirm the good specificity previously published by others. They tested it in a murine model, comparing an infection with living $S$. aureus, to a sterile inflammation with heat killed bacteria or turpentine oil. Experimental data showed a renal excretion and a poorly specific accumulation in the infected muscle in comparison to inflamed and normal muscles. The T/NT ratio in infected muscles was $3.39 \pm 0.6$ at $3 \mathrm{~h}$ post injection, while the $T / \mathrm{NT}$ in muscles with turpentine oil or with heat killed bacteria were, respectively, $3.12 \pm 0.35$ and $2.48 \pm 0.45$ always at $3 \mathrm{~h}$ post injection with no statistically significant difference between the 3 groups [91]. Finally, Sohaib et al. [92] confirmed the ability of this radiopharmaceutical to discriminate the infection from inflammation. ${ }^{99 \mathrm{~m}} \mathrm{Tc}$-ceftriaxone was tested in rats, infected with $10^{8} \mathrm{CFU}$ of $S$. aureus or E. coli, whereas turpentine oil was used in control rats. Biodistribution studies revealed a main renal excretion, followed by liver and intestine, and high accumulation in the infectious area in animals injected with E. coli rather than $S$. aureus or turpentine oil. These data were confirmed by $T / \mathrm{NT}$ ratios equal to $12.66 \pm 1.44$, $2.35 \pm 0.21$ and $1.4 \pm 0.01$, respectively, suggesting that ${ }^{99} \mathrm{~m}$ Tc-ceftriaxone could be used as a microbial imaging agent only for E. coli.

Another third-generation antibiotic, studied by Mirshojaei et al. is ceftazimide. It was labelled with ${ }^{99 \mathrm{~m}} \mathrm{Tc}$ and its biodistribution was tested in normal and $S$. aureus infected mice. Data showed a similar uptake of radiopharmaceutical in non target organs (liver, spleen, heart and lung) between 
control and infected animals with lower hepato-biliary excretion when compared to ${ }^{99 \mathrm{~m}} \mathrm{Tc}$-ciprofloxacin; about accumulation in the infected and control muscle, the ratio was $1.4 \pm 0.2$ at $1 \mathrm{~h}$ post injection and $1.1 \pm 0.1$ at $4 \mathrm{~h}$. Therefore, ceftazimide did not show the same specificity of ceftizoxime and ceftriaxone, as bacterial imaging agent [93].

Cefoperazone is another third-generation cephalosporine, studied to evaluate the best radiolabelling conditions with ${ }^{99 \mathrm{~m}} \mathrm{Tc}$ and its biological distribution in a rat model of $S$. aureus bacterial infection. In vivo results, expressed as $\% \mathrm{ID} / \mathrm{g}$, showed a renal clearance and a 4.5 -fold higher uptake in the infected tissue than control, with a maximum $T / \mathrm{NT}$ ratio at $45 \mathrm{~min}$ post injection of $4.66 \pm 0.53$ : then this value decreased with time $(2.9 \pm 0.75$ at $5 \mathrm{~h})$, probably because of bacterial killing by radiopharmaceutical or clearance from circulation. These data make cefoperazone a promising agent for detection of infectious foci, even if it needs further investigations [94].

Belonging to fourth-generation of cephalosporins is cefepime, whose biological efficacy and specificity were compared to gatifloxacin, a fluoroquinolone derivative. The two radiopharmaceuticals were labelled with ${ }^{99 \mathrm{~m}} \mathrm{Tc}$ and tested in rats infected with living E. coli, heat killed bacteria and turpentine oil. After successful in vitro quality controls and bacterial binding assay, biodistribution studies were performed and results demonstrated a liver uptake for both radiopharmaceuticals that decreases with time. The uptake in the infectious foci was better for ${ }^{99 \mathrm{~m}} \mathrm{Tc}$-cefepime than for ${ }^{99 \mathrm{~m}}$ Tc-gatifloxacin (T/NT ratio was $8.4 \pm 0.1$ at $3 \mathrm{~h}$ post injection for ${ }^{99 \mathrm{~m}} \mathrm{Tc}$-cefepime and $4.5 \pm 0.3$ for ${ }^{99 \mathrm{~m}} \mathrm{Tc}$-gatifloxacin in infected muscles with living bacteria): Thus, cefepime was able to distinguish between sterile and septic inflammation better than all other antibiotics [95].

\section{Inhibitors of nucleic acid synthesis}

The inhibition of nucleic acid synthesis occurs through the binding of the antimicrobial to DNA-dependent RNA polymerase, blocking the initiation of RNA synthesis, or to DNA gyrase, inhibiting DNA synthesis [96].

Rifampicin is particularly indicated for the treatment of tuberculosis, and recently an imaging agent for PET use has been developed for latent tuberculosis detection, labelled with ${ }^{11} \mathrm{C} .{ }^{11} \mathrm{C}$-rifampicin was tested in preclinical studies to evaluate whether there is sufficient drug in the infected site because the radiopharmaceutical is able to accumulate in a hypoxic environment like the tuberculotic granuloma [97].

However, in animals rifampicin was studied for detection of methicillin-resistant $S$. aureus (MRSA) infections in both rats and rabbits. Turpentine oil induced inflammation is always the method of choice for control. After labelling with ${ }^{99 \mathrm{~m}} \mathrm{Tc}$, biodistribution revealed a long renal clearance, and a high accumulation in the infectious foci, confirmed by in vivo calculated $T / \mathrm{NT}$ ratio $(7.34 \pm 0.74$ at $90 \mathrm{~min}$ post injection) [98].

Another antibiotic that indirectly acts on nucleic acid, in particular DNA, is nitrofurantoin: it is often used for urinary tract infections because many uropathogens have not yet developed resistance to it. Its mechanism of action is still unclear, but it seems that bacterial nitroreductase enzymes transform the antibiotic into more reactive intermediates that lead to single-strand breaks in DNA through interaction with bacterial ribosomal proteins [99]. ${ }^{99 \mathrm{~m}} \mathrm{Tc}-$ nitrofurantoin was investigated in $E$. coli infected rats and rabbits. In vivo distribution showed an early uptake in the liver and stomach, while the accumulation in infectious foci rapidly increased in a time-dependent manner as compared to controls, with a peak at 90 min p.i., with a $T /$ NT ratio equal to $4.83 \pm 1.13$ [100].

\section{Inhibitors of bacterial cell wall synthesis}

This category of antibiotics may inhibit many steps of cell wall synthesis, above all the inhibition of peptidoglycan synthesis, because cell wall is essential for survival of bacteria; but also the membrane transport mechanisms, resulting in osmotic lysis [101].

An example of these antibiotics is the well-known amoxicillin, a penicillin derivative that acts by inhibiting the third and last stage of bacterial cell wall synthesis. It is particularly active on S. pneumoniae [102]. Amoxicillin was recently labelled with ${ }^{99 \mathrm{~m}} \mathrm{Tc}$ and its biological distribution was studied in $S$. pneumoniae infected rabbits. Results were promising but not as good as for other radiolabeled antibiotics and maximum accumulation in the infection was recorded $2 \mathrm{~h}$ post-injection [103].

By contrast, alafosfalin is a dipeptide phosphonic acid, active against both Gram-positive and Gram-negative bacteria. It inhibits the early stage of peptidoglycan synthesis because it mimics the terminal dipeptide moiety (DAla-D-Ala), inhibiting the enzyme D-Ala-D-Ala synthetase, or inhibits the enzyme alanine racemase for its affinity to racemase cofactors [104]. When labelled with ${ }^{99 \mathrm{~m}} \mathrm{Tc}$ it showed rapid renal excretion in rats, infected with $10^{8} \mathrm{CFU}$ of $S$. Aureus. Interestingly, Tsopelas et al. compared ${ }^{99 \mathrm{~m}} \mathrm{Tc}$-alafosfalin with ${ }^{99 \mathrm{~m}} \mathrm{Tc}-\mathrm{DTPA}$ and ${ }^{99 \mathrm{~m}} \mathrm{Tc}-\mathrm{la}$ belled-leukocytes and showed that the T/NT ratio at $4 \mathrm{~h}$ p.i. for ${ }^{99 \mathrm{~m}} \mathrm{Tc}$-alafosfalin was higher than for ${ }^{99 \mathrm{~m}} \mathrm{Tc}$-DTPA $(4.32 \pm 0.26$ vs $1.93 \pm 0.15)$ but lower than for ${ }^{99 \mathrm{~m}} \mathrm{Tc}$ WBC. These results were also confirmed by scintigraphic images and histological studies, suggesting that ${ }^{99 \mathrm{~m}} \mathrm{Tc}$ - 
alafosfalin complex is not as specific as WBC for detecting bone infections, particularly in case of high probability of infection [105].

The bacterial cell wall is mainly composed by peptidoglycan, which is formed from alternating units of $\mathrm{N}$ acetylglucosamine and $\mathrm{N}$-acetylmuramic acid. The introduction of positron emitter isotope into $\mathrm{N}$-acetylglucosamine structure could be a solution for the detection bacteria using PET imaging [5]. Thus, Martìnez et al. described a new labelling method of 2-deoxy-2- $\left[{ }^{18} \mathrm{~F}\right]$ fluoroacetamido-D-glucopyranose $\left(\left[{ }^{18} \mathrm{~F}\right] \mathrm{FAG}\right)$ trough microwave irradiation, and demonstrated its ability to discriminate, in vivo, a bacterial infection from a sterile inflammation. They used a mouse model, infected with $10^{7}$ CFU of E. coli or a sterile inflammation with turpentine oil for biodistribution studies and rats for acquiring PET images, followed by histology and immunostaining of relevant tissues. Images showed a high accumulation of $\left[{ }^{18} \mathrm{~F}\right] \mathrm{FAG}$ in the infectious foci, similar to $\left[{ }^{18} \mathrm{~F}\right] \mathrm{FDG}$, but there was no uptake of $\left[{ }^{18} \mathrm{~F}\right] \mathrm{FAG}$ in the sterile inflammatory lesion as compared to $\left[{ }^{18} \mathrm{~F}\right] \mathrm{FDG}$. Haematoxylin-eosin and immunostaining using anti-E. coli antibodies confirmed the presence of bacteria in the infected tissue and an infiltration of granulocytes and macrophages, while in turpentine oil-induced inflammation, neutrophils and macrophages prevailed, demonstrating that $\left[{ }^{18} \mathrm{~F}\right] \mathrm{FAG}$ is able to distinguish bacterial infections from inflammation in contrast to $\left[{ }^{18} \mathrm{~F}\right] \mathrm{FDG}[106]$.

Another antibiotic that inhibits the bacterial cell wall synthesis is vancomycin. Because of its big size and complex structure, vancomycin does not enter the membrane of Gram-negative bacteria, but binds to peptidoglycan precursors, preventing their lipid carrier-mediated transfer through the membrane [107]. Vancomycin was also labelled with ${ }^{99 \mathrm{~m}} \mathrm{Tc}$ and in vitro studies (binding assay to bacteria and stability test) were performed as well as in vivo studies (biodistribution and targeting in $S$. aureus infected rats). Results showed both liver and kidneys metabolism and a high uptake of in the infected muscle with a $T / \mathrm{NT}$ ratio equal to 5 at $60 \mathrm{~min}$ post injection [108].

\section{Inhibitors of protein synthesis}

Protein synthesis inhibitors include various classes of antibiotics, each of which blocks the process in a different way, in particular at the ribosomal level [109].

An example is kanamycin, a bactericidal agent of aminoglycoside family, used for the treatment of infections when penicillin cannot be used such as bone, skin or abdominal infections. Its mechanism of action is the premature chain termination and RNA codon misreading by the interference with $30 \mathrm{~S}$ ribosome. It was labelled with
${ }^{99 \mathrm{~m}}$ Tc by a simple and easy procedure and then tested in rats for in vivo distribution and in rabbits for scintigraphy, in which infection was induced with $2 \times 10^{8} \mathrm{CFU}$ of $S$. aureus. The tissue distribution showed a renal elimination and a high uptake in the infectious foci as compared to normal muscle used as control, with a $T / \mathrm{NT}$ ratio greater than 2 up to $24 \mathrm{~h}$ from injection [110].

Belonging to these inhibitors there are two other antibiotics, doxycycline hyclate (DOX) and erythromycin. DOX is an antibacterial tetracycline derivative, with a wide range of activity against Gram-negative and Gram-positive bacteria; it binds to $30 \mathrm{~S}$ subunit of ribosome, preventing the binding between aminoacyl tRNA and the acceptor site on mRNA. ${ }^{99 \mathrm{~m}}$ Tc-DOX was tested in vivo in rats, infected with $4 \times 10^{10} \mathrm{CFU}$ of $E$. Coli. The excretion was mainly through kidneys, but also through stomach because of high intestinal activity despite liver uptake was low. The highest $T / \mathrm{NT}$ ratio was $2.62 \pm 0.88$ after $5 \mathrm{~h}$ from the radiotracer injection. According to previous studies, the radiopharmaceutical had a high uptake both in the infected and inflamed thigh muscle, indicating that ${ }^{99 \mathrm{~m}}$ Tc-DOX cannot differentiate bacterial infection from sterile inflammation [111].

Erythromycin is a bacteriostatic agent of macrolides family and it inhibits the transpeptidation or translocation because of a missed binding of tRNA to the specific site by the binding to 50S ribosomal subunit [96]. Biodistribution studies were performed in mice infected with $10^{5}-10^{6} \mathrm{CFU}$ of $S$. aureus or turpentine oil as control. Experimental data showed a main elimination through renal and urinary pathway at $4 \mathrm{~h}$ from injection of radiotracer and a liver uptake that decreased with time. The $T / \mathrm{NT}$ ratio of ${ }^{99 \mathrm{~m}} \mathrm{Tc}$ erythromycin in infected muscle was greater than ciprofloxacin $(5 \pm 0.6$ vs $3.8 \pm 0.8)$ at $30 \mathrm{~min}$ post injection, but at the same time values of $T / \mathrm{NT}$ ratio were comparable in infected and inflamed mice, respectively $5 \pm 0.6$ and $4.8 \pm 0.4$. Thus, ${ }^{99 m}$ Tc-erythromycin complex accumulates in infected muscles, but it cannot distinguish between septic and aseptic inflammation [112]. Another not very specific antibiotic of this category is vibramycin. It was labelled with ${ }^{99 \mathrm{~m}} \mathrm{Tc}$ and then tested in a rats. The infection was induced with $2 \times 10^{8} \mathrm{CFU}$ of live $\mathrm{S}$. aureus, while for the inflammation heat-killed bacteria or turpentine oil were used. Biodistribution revealed a main hepato-biliary excretion and not high accumulation of radiopharmaceutical in the infectious site compared to controls, confirmed by similar values of $T / \mathrm{NT}$ ratios $(2.64,2.15$ and 1.80 , respectively in live bacteria, heat killed bacteria and turpentine oil). Therefore these results show that ${ }^{99 \mathrm{~m}} \mathrm{Tc}$-vibramycin cannot be considered a specific infection imaging agent [113].

By contrast, azithromycin, clarithromycin and clindamycin are three inhibitors of protein synthesis, which 


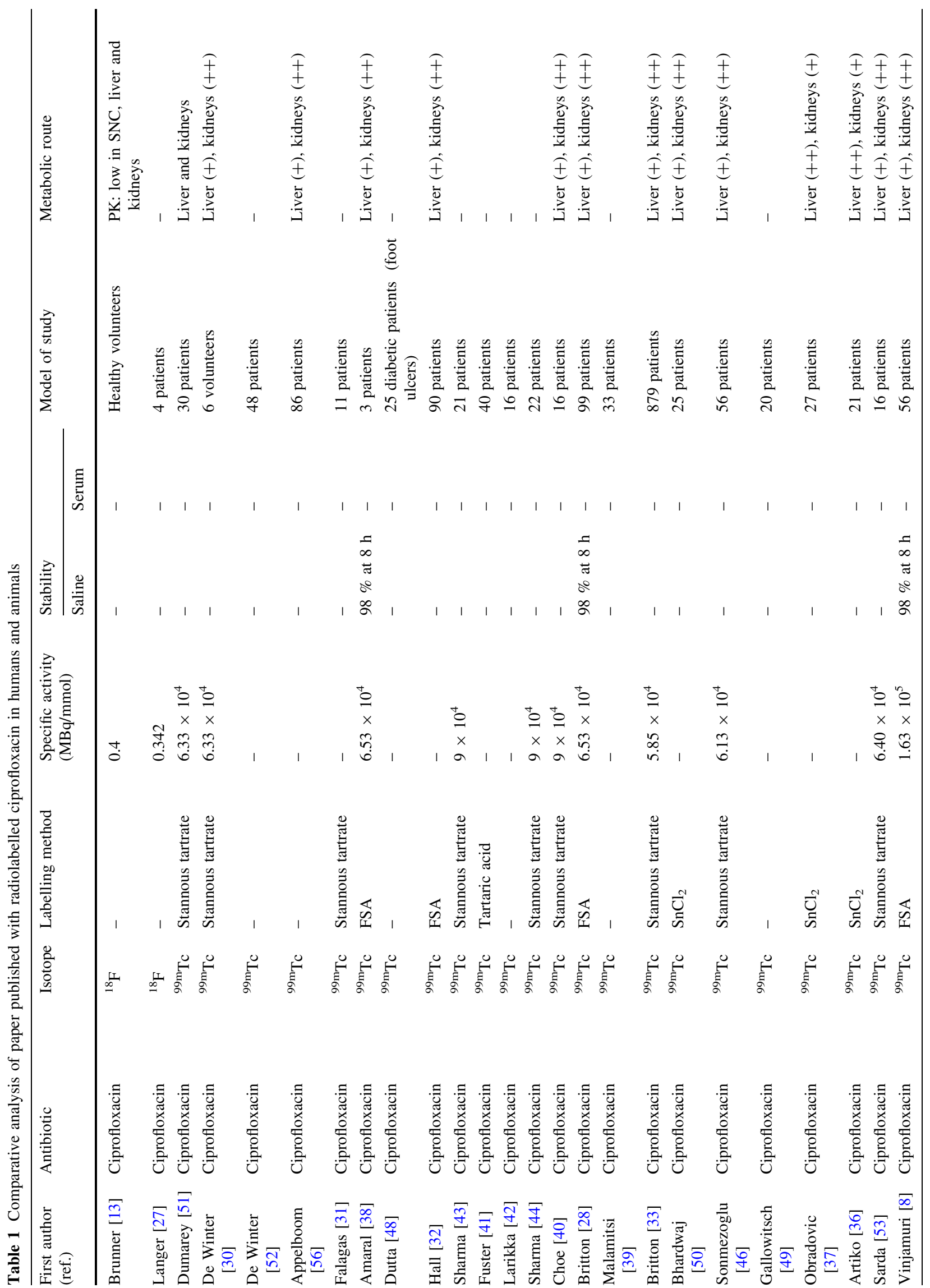




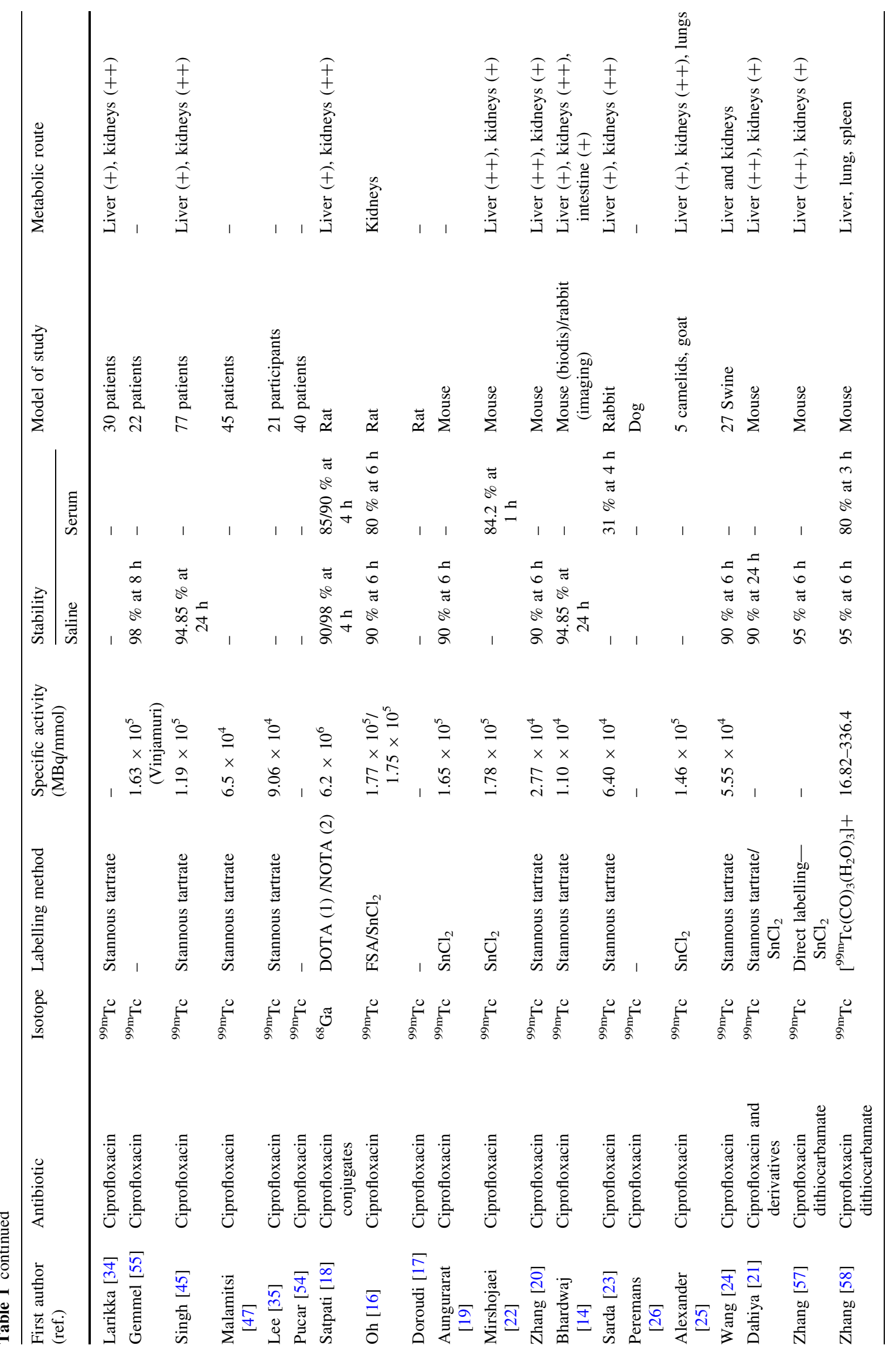




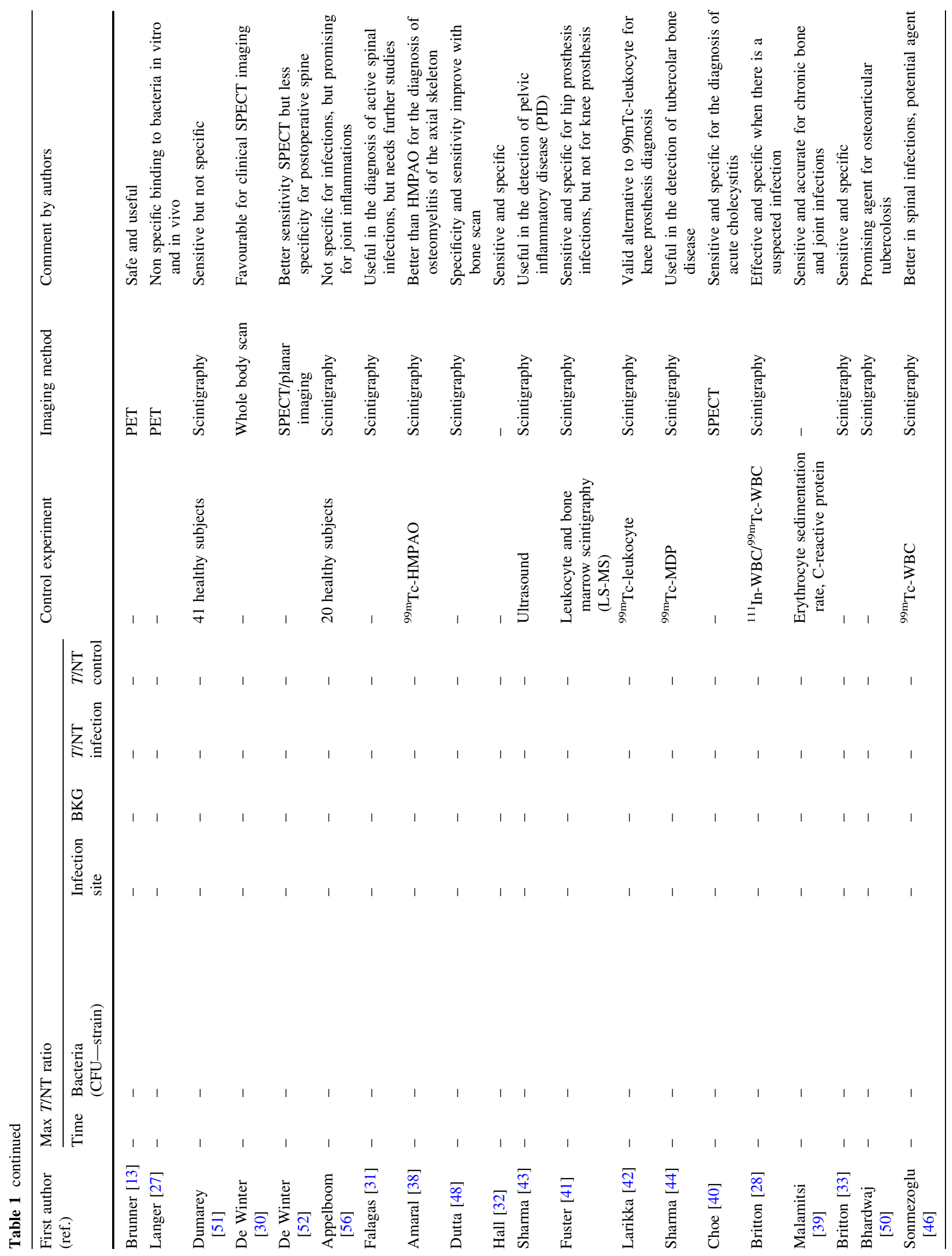




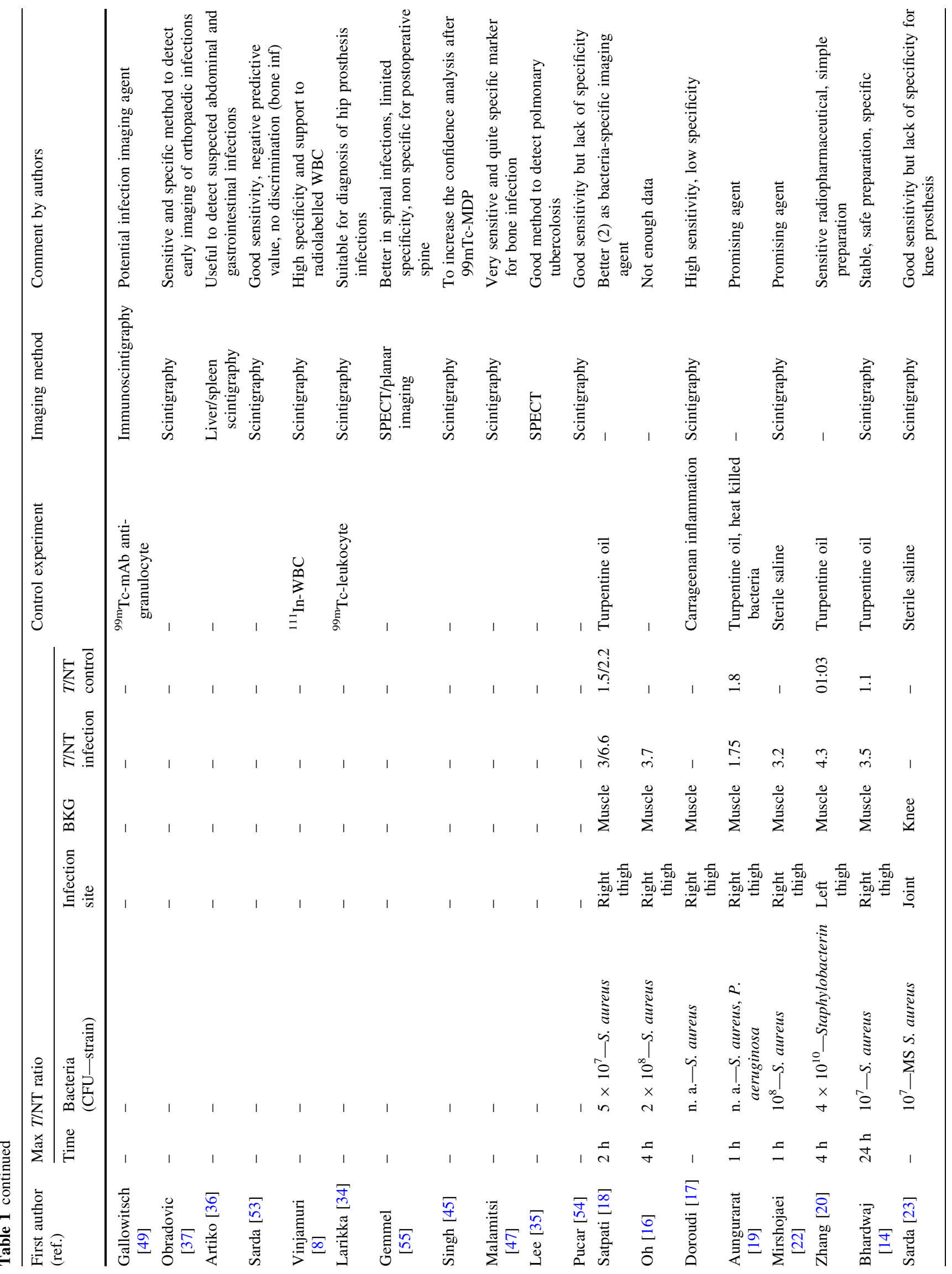




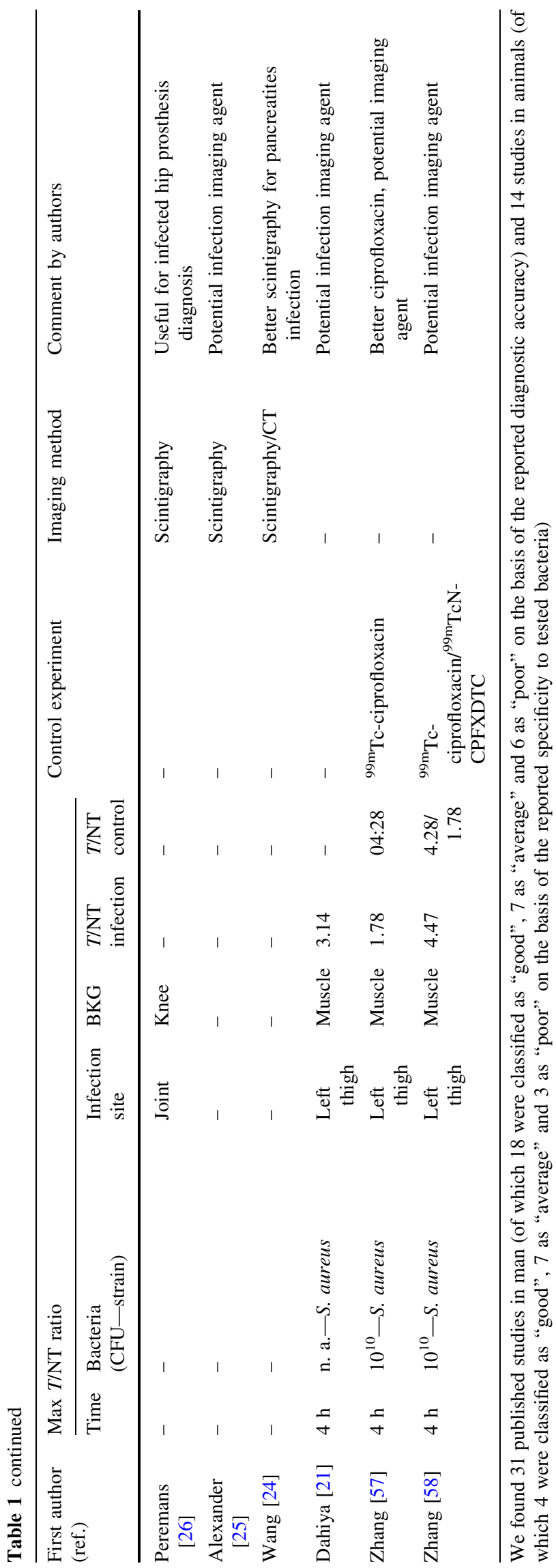

could be novel potential bacterial imaging agents. Azithromycin, like erythromycin, belongs to macrolides, but differs for the structure and the activity level against Grampositive and Gram-negative bacteria [114]. It was also labelled with ${ }^{99 \mathrm{~m}} \mathrm{Tc}$ and biodistribution studies were performed in mice, where infection was induced with $S$. aureus in the thigh muscle. Inflammation was induced with direct injection of turpentine oil and heat killed bacteria. The quantitative evaluation, expressed as the percentage of injected dose per organ, showed an excretion through kidneys and urine, and high accumulation in infectious muscle than controls, confirmed by the $T / \mathrm{NT}$ ratio: the maximum peak was $6.20 \pm 0.12$ at $2 \mathrm{~h}$ post-injection, but at all time intervals values were significantly higher than sterile inflamed muscles [115].

Clarithromycin is a derivative of erythromycin and it was labelled with ${ }^{99 \mathrm{~m}} \mathrm{Tc}$. Mice infected with $10^{8} \mathrm{CFU}$ of $S$. aureus were used as a model, while turpentine oil and heat killed bacteria were used as control. Biodistribution showed an excretion of radiopharmaceutical mainly through the urinary pathway and a high uptake in the site of infection was observed as compared to controls. T/NT ratios were $7.33 \pm 0.13$ at $2 \mathrm{~h}$ for the infection model, while $3.1 \pm 0.13$ and $3.26 \pm 0.12$ for turpentine oil and heat killed bacteria, confirming the ability of ${ }^{99 \mathrm{~m}} \mathrm{Tc}$-clarithromycin to distinguish between septic and sterile inflammation [116].

Clindamycin is an antibiotic of lincosamide family, used for treatment of streptococci and staphylococci infections. It binds to the 23S rRNA of the 50S ribosomal subunit, inhibiting the initial stage of the elongation cycle during protein synthesis [117]. After labelling with ${ }^{99 \mathrm{~m}} \mathrm{Tc}$, in vivo distribution and scintigraphic imaging were performed, respectively in rats and rabbits. The infection was induced using $2 \times 10^{8} \mathrm{CFU}$ of $S$. aureus, while inflammation with turpentine oil and heat killed bacteria. ${ }^{99 \mathrm{~m}} \mathrm{Tc}$-clindamycin was eliminated through kidneys and it mostly accumulated in the infectious foci as compared to inflamed muscles, indicating a specific binding to living bacteria. However, the $T / \mathrm{NT}$ ratio was not very high, since it was $3.1 \pm 0.3$ after $1 \mathrm{~h}$ post-injection [118].

\section{Others}

Mebendazole is an anthelmintic drug with a broad spectrum against nematodal and cestodal species; it belongs to the imidazole group and it is particularly indicated for the treatment of trichinellosis [119]. In fact, in the study performed by Inceboz et al. [120], the authors wanted to investigate the biodistribution of ${ }^{99 \mathrm{~m}} \mathrm{Tc}$-mebendazole in a rat model, infected with $T$. spiralis, a nematode that is often present in wild carnivorous animals. Briefly, 750-1000 larvae were orally administrated in rats to induce infection 


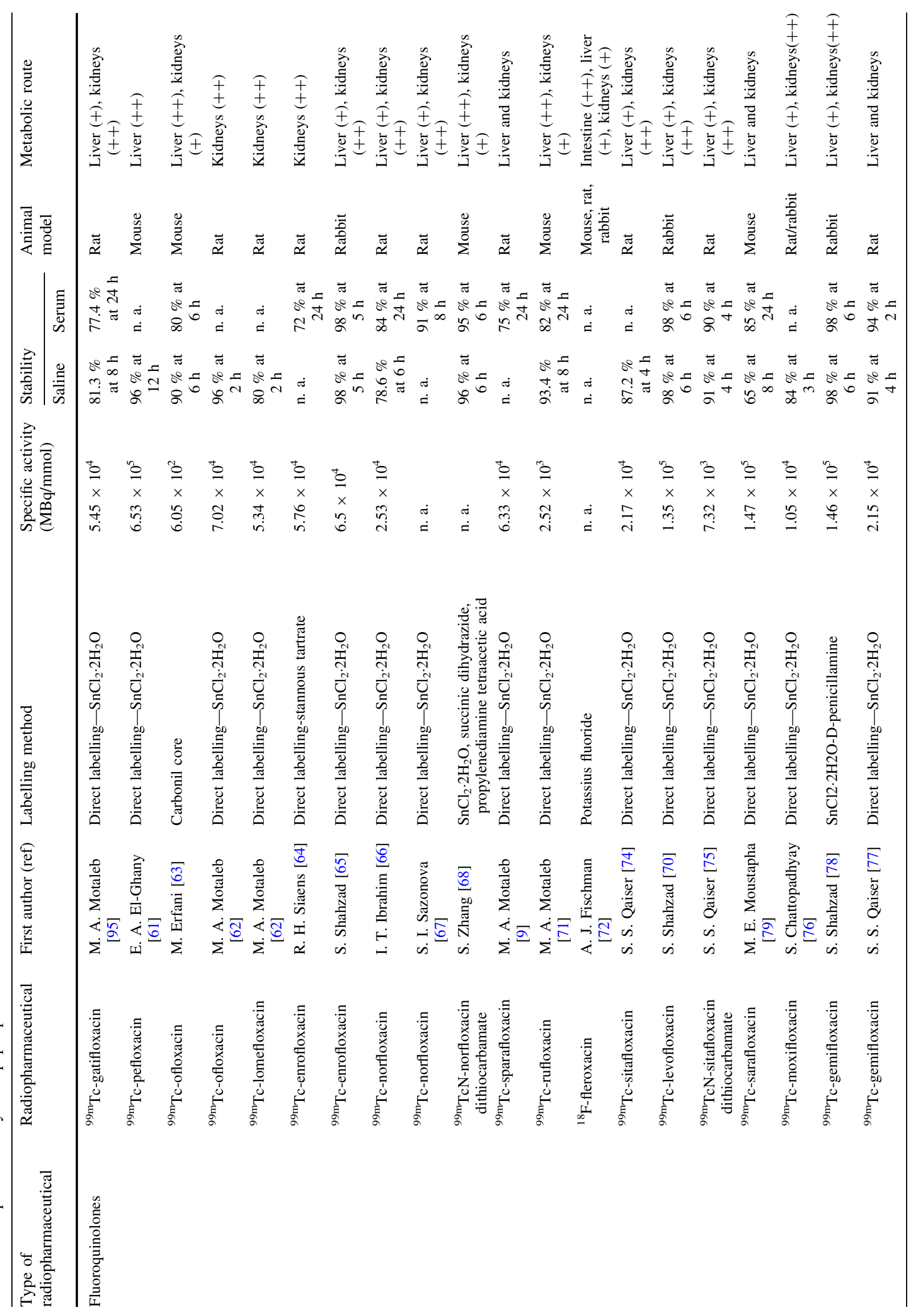




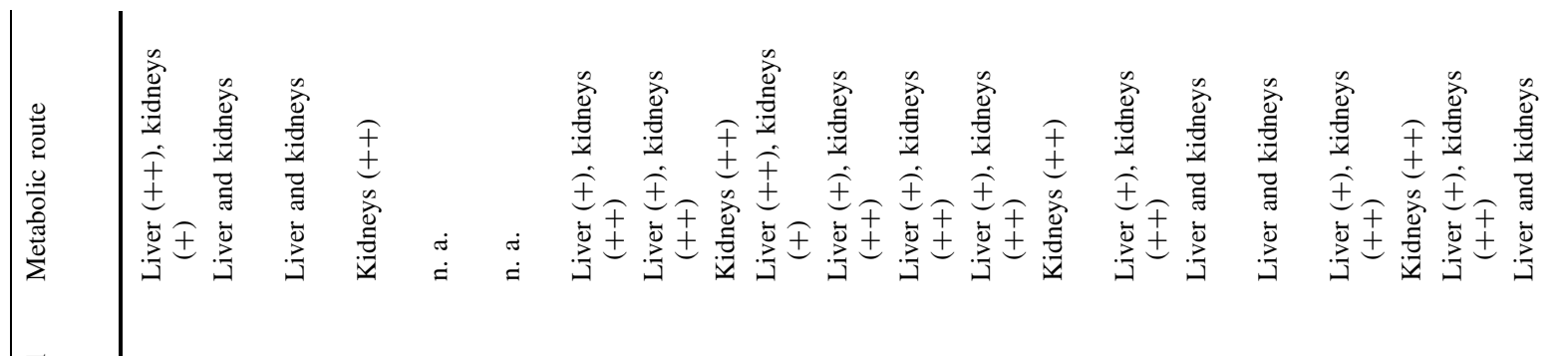

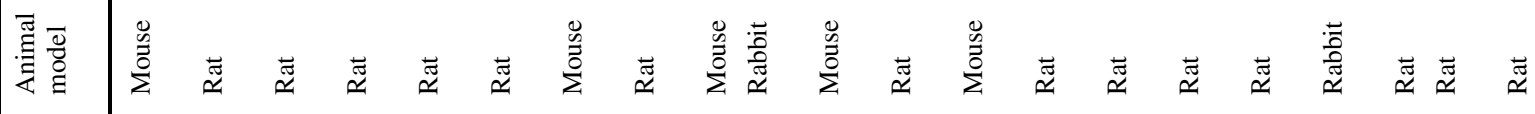

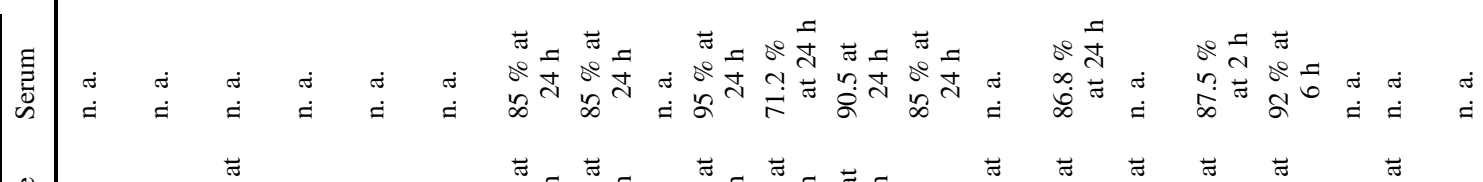

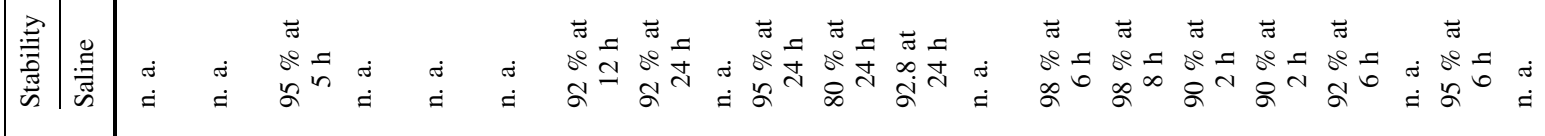

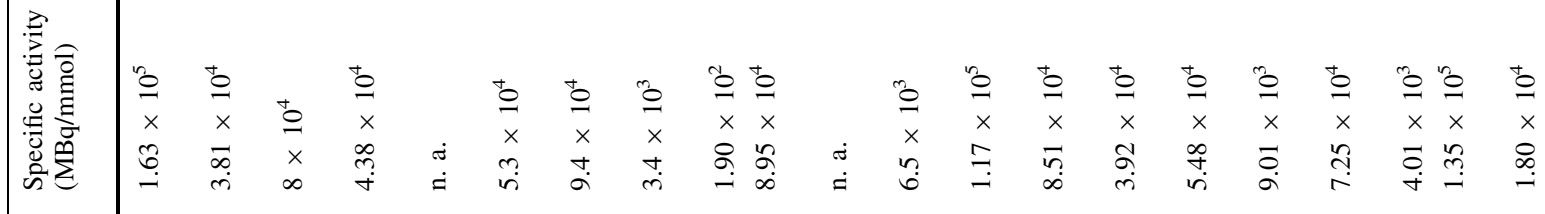

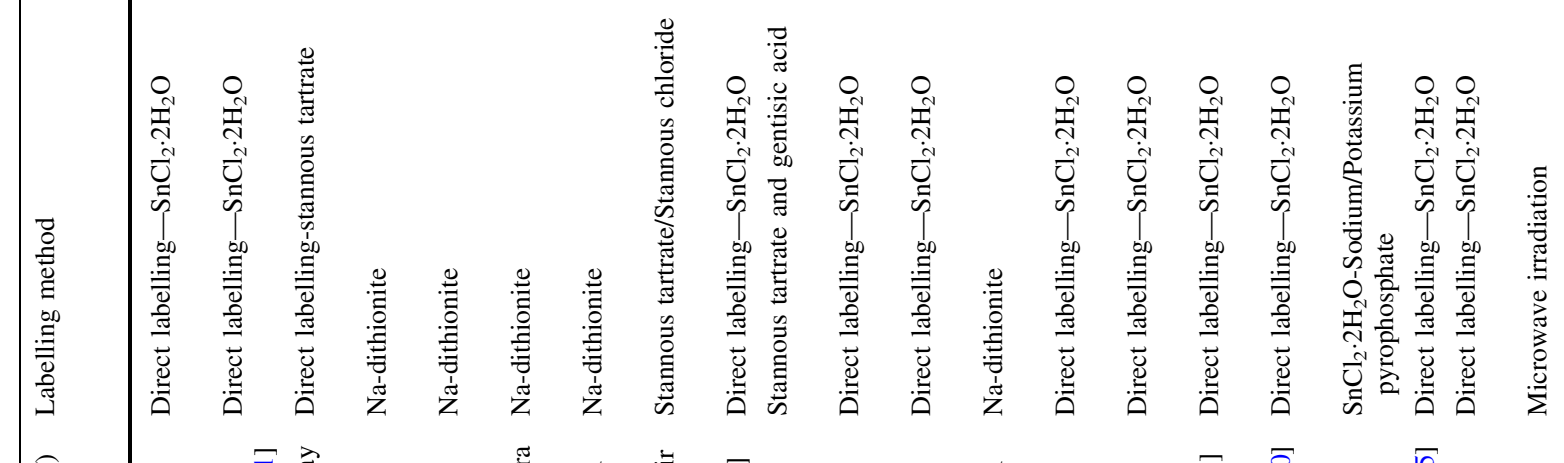

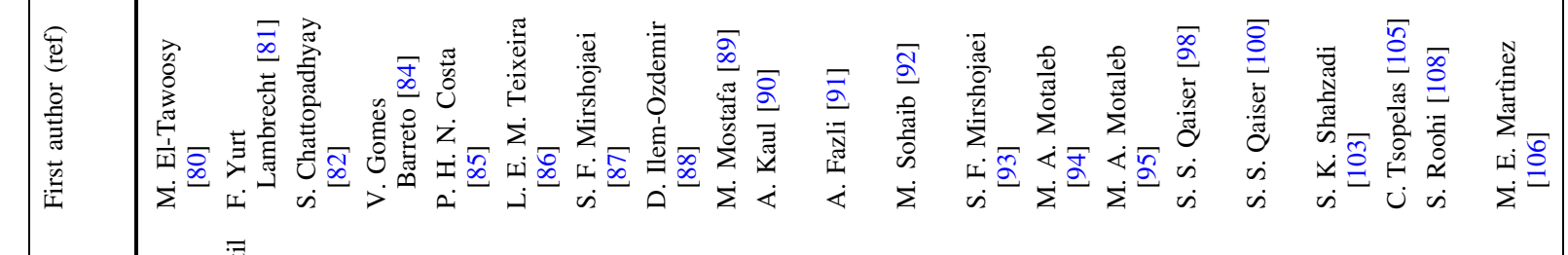

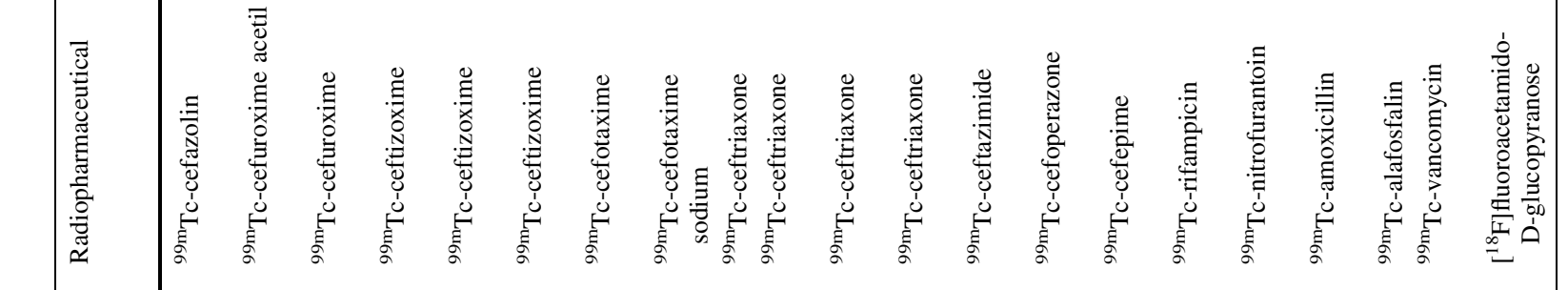

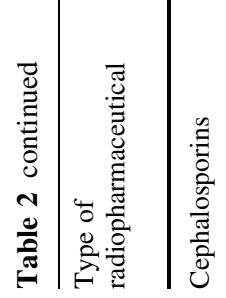

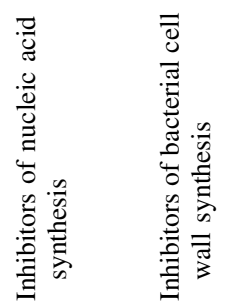




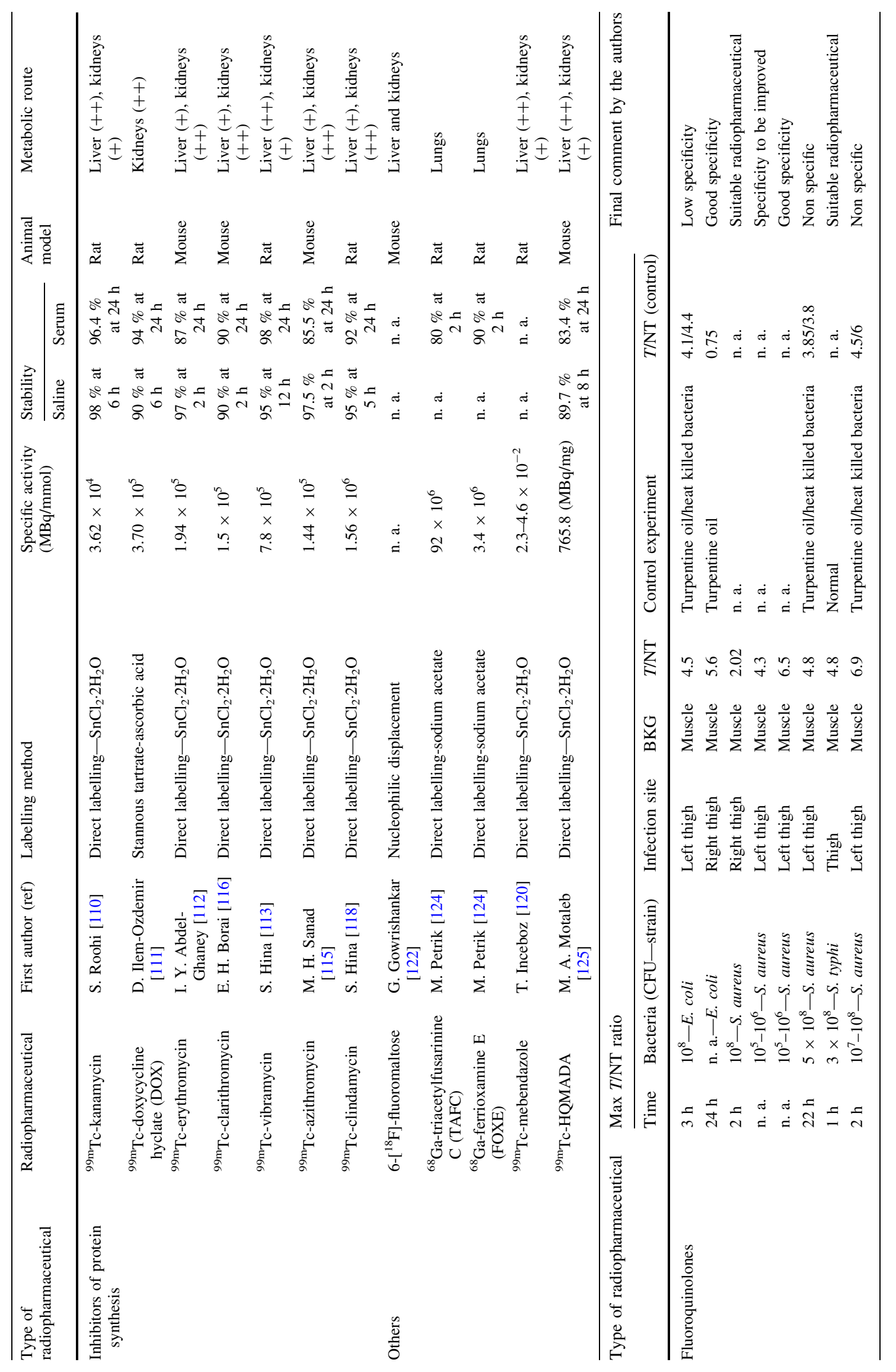




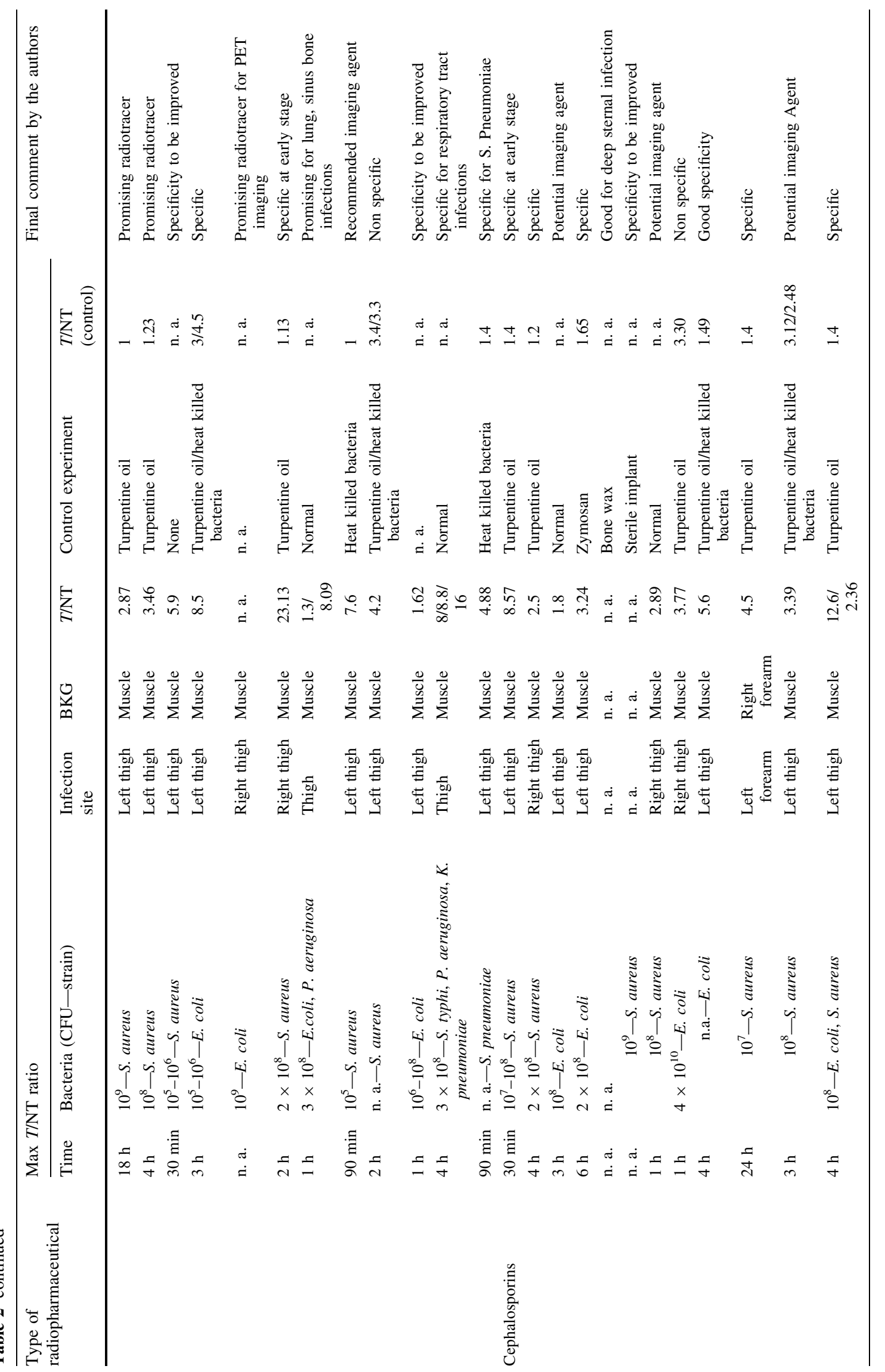




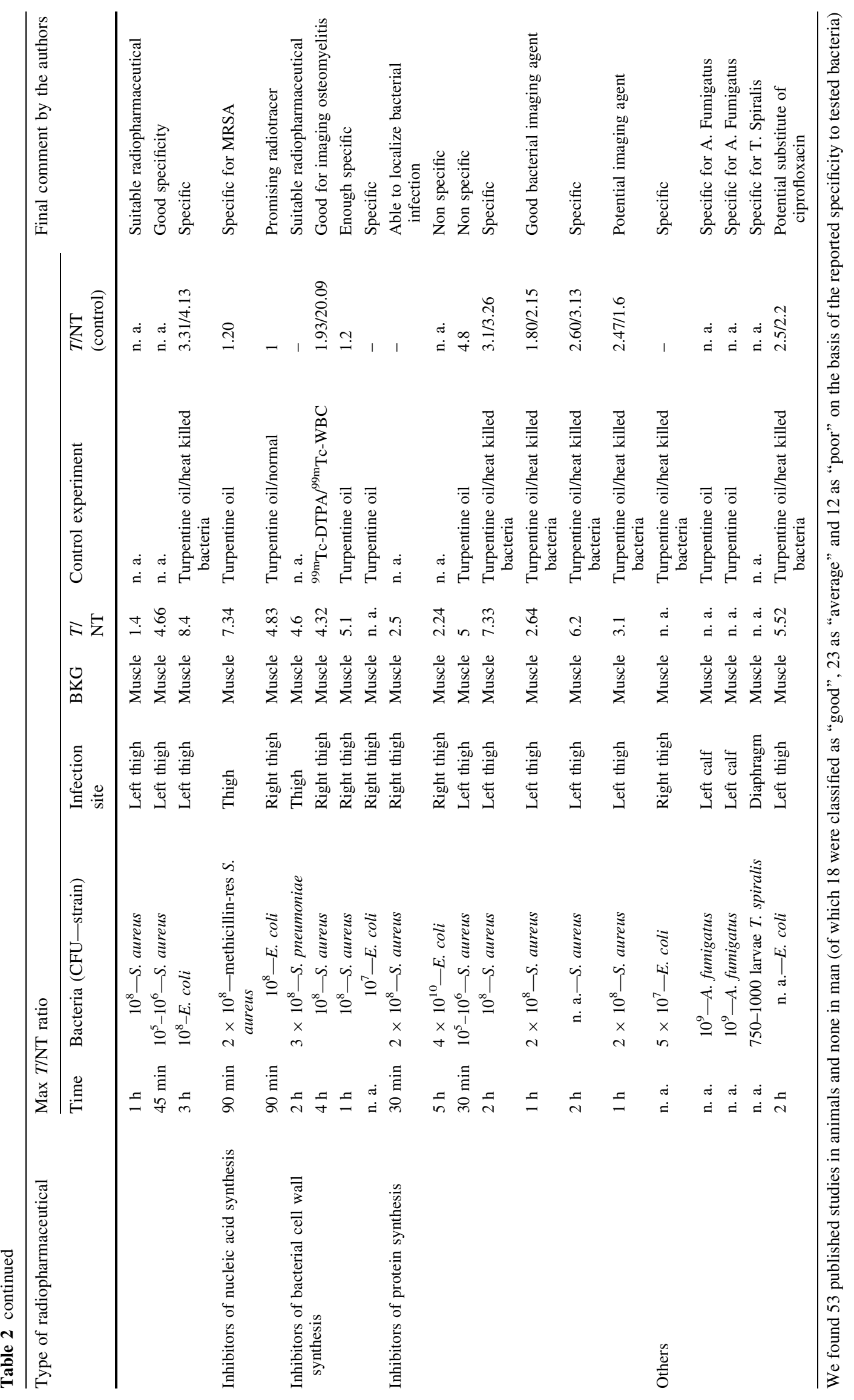


in the muscles, while healthy rats were used as controls. Once the infection was established, ${ }^{99 \mathrm{~m}} \mathrm{Tc}$-mebendazole was given to rats by oral administration or through a tail vein. Biodistribution data showed a main uptake in the gastro-intestinal tract, if the administration was oral, while in kidney if it was injected i.v. The maximum uptake in muscles was found in the tongue and the diaphragm for both groups, but also in other infected muscles such as masseter or semimembranosus muscle, suggesting that ${ }^{99 \mathrm{~m}}$ Tc-mebendazole complex could be a useful imaging agent to detect $T$. spiralis infections.

Fluoromaltose is another molecule through which it is possible to distinguish bacterial infections in vivo from other pathologies. In this case maltodextrin-based imaging probes (MDPs) were used, exploiting a bacteria-specific mechanism of transport, called maltodextrin transporter, which is absent in mammalian cells. These probes were internalized only by bacteria with a rapid metabolism with high sensitivity, detecting low number or bacteria and discriminating between infection and inflammation [121]. Based on these considerations, Gowrishankar et al. [122] labelled 6-fluoromaltose with ${ }^{18} \mathrm{~F}$ to evaluate its ability to differentiate bacterial infection from inflammation in a murine model. Infection was induced with $5 \times 10^{7} \mathrm{CFU}$ of E. coli, while the inflammation was produced with $10^{8}$ CFU of heat-killed bacteria and turpentine oil. Micro PET/ CT images were acquired as well as biodistribution studies and histology. A 3D color map from PET/CT images showed a clear accumulation of $6-\left[{ }^{18} \mathrm{~F}\right]$-fluoromaltose in the infected muscle compared to non infected muscle and a renal and hepatobiliary excretion, confirmed by biodistribution, histological images and bioluminescence imaging.

Triacetylfusarinine $\mathrm{C}$ (TAFC) and ferrioxamine $\mathrm{E}$ (FOXE) are two siderophores, which are produced by various microorganisms for the binding and storage of iron. Indeed iron is essential for many metabolic processes of microorganisms. In biofilms specific transporters for ${ }^{68} \mathrm{Ga}-$ siderophores are upregulated, resulting in an accumulation of the radiopharmaceutical in bacteria. Considering the similar chemistry of iron and gallium, Petrik et al. $[123,124]$ investigated the possibility to label TAFC and FOXE with ${ }^{68} \mathrm{Ga}$ and then they evaluated the capacity of radiopharmaceuticals to localize infection by A. fumigatus in a rat model. In vitro studies were also performed and included a comparison of uptake between different bacteria (A. fumigatus, P. aeruginosa, S. aureus) and human lung cancer cells. In vivo studies showed a rapid accumulation of ${ }^{68} \mathrm{Ga}-\mathrm{TAFC}$ and ${ }^{68} \mathrm{Ga}$-FOXE in A. fumigatus infected tissues, especially in lungs, while a moderate uptake in the turpentine oil inflamed muscle and no uptake in $S$. aureus infected muscle was observed. These data support the conclusion that ${ }^{68} \mathrm{Ga}$-TAFC and ${ }^{68} \mathrm{Ga}$-FOXE are selective agents to detect A. fumigatus infection through PET imaging, with a higher sensitivity for ${ }^{68} \mathrm{Ga}$-FOXE.

Finally, 2,2'-[(8-hydroxyquinolin-7-yl) methylazanediyl] diacetic acid (HQMADA) is an antibacterial drug, deriving from the reaction between 8-hydroxyquinoline and iminodiacetic acid in presence of paraformaldehyde. It was labelled with ${ }^{99 \mathrm{~m}} \mathrm{Tc}$ and, after in vitro studies such as stability in serum and binding to bacteria, biodistribution was studied in E. coli mice. Experimental data revealed a main uptake in liver and intestine and a high accumulation in the infectious foci than in sterile inflammation. T/NT ratio was $5.52 \pm 0.2$ between infected and healthy muscle after $2 \mathrm{~h}$ from injection, while in the inflamed model, both with turpentine oil and heat-killed $E$. coli, the $T / \mathrm{NT}$ ratios were nearly 2 at each time point, suggesting that ${ }^{99 \mathrm{~m}} \mathrm{Tc}-\mathrm{HQMADA}$ complex can differentiate bacterial infection from sterile inflammation [125].

\section{Summary of systematic analysis of the literature}

The systematic analysis was performed by searching in PubMed, Web of Science, Scopus and Google Scholar websites, for "radiolabelled OR radiolabeled OR labelled OR labeled AND antibiotic* AND bacteria*". We obtained 1193 papers from PubMed of which 25 original articles were considered, and eight reviews, one case report and one editorial were excluded. These papers were integrated with similar search in other websites, finally obtaining 81 original published studies that were analysed and included in this systematic review and summarized in Tables 1 and 2. We considered: the type of isotope, the labelling method, the specific activity of radiopharmaceutical, its stability in serum and/or saline, the animal model used, the metabolic route, the control experiment and the obtained results in terms of target muscle/background ( $T /$ NT) ratio, with the purpose of having an objective analysis as complete as possible.

Ciprofloxacin studies were selected and used as comparison to other antibiotics because ciprofloxacin was the first antibiotic tested in humans. As shown in Table 1, many groups worldwide obtained conflicting results in terms of sensibility and specificity. Overall, in animal models ciprofloxacin showed good sensibility but a lack of specificity, probably because of labelling issues and poor stability. In clinical studies data are more complicated to analyse because different authors used different scoring systems that may result subjective to interpretation [29], as it can be seen in Table 1. A multicentre study with homogeneous criteria of image acquisition and interpretation is still missing. 
Table 2 shows the results of our analysis of all other radiolabelled antibiotics. None was studied in man. It is possible to note that very often different studies are performed by the same group of authors. Overall studies are published in journals with low impact factor and relevance. There is low reproducibility and reliability because most antibiotics were not tested by more than one team. Sometimes reports are incomplete with no in vitro and/or in vivo data and it was not possible to analyse all experimental results. It is anyhow remarkable to observe the variability of labelling procedure, and the high variability of specific activity of the radiopharmaceutical. Often stability in serum or saline are not performed or not for enough time. Animal models are variable and the type of bacteria used and CFU injected is extremely variable. In particular the number of bacteria used may be relevant because higher numbers can give a higher signal by binding more molecules of radiopharmaceutical [7].

Mainly the infection was induced using S. aureus or $E$. coli, except when the antibiotic was specific for a certain bacterium such as A. fumigatus or T. spiralis. The metabolism of most radiopharmaceuticals is renal and rarely hepatic. The specificity is related to in vivo calculated target to background ratio (T/NT) using turpentine oil and/ or heat killed bacteria as control. Very rarely we found in vitro data on binding to bacteria or ex vivo autoradiography to demonstrate the specificity of binding to bacteria. Most $T / \mathrm{NT}$ ratios were below 4 (poor radiopharmaceuticals), a few were between 4 and 8 (promising radiopharmaceuticals), and only ${ }^{99 \mathrm{~m}} \mathrm{Tc}$-cefazolin, ${ }^{99 \mathrm{~m}} \mathrm{Tc}$-cefepime, ${ }^{99 \mathrm{~m}}$ Tc-clarithromycin, ${ }^{99 \mathrm{~m}}$ Tc-rufloxacin, ${ }^{99 \mathrm{~m}}$ Tc-ceftriaxone, ${ }^{99 \mathrm{~m}} \mathrm{Tc}$-levofloxacin, ${ }^{99 \mathrm{~m}} \mathrm{Tc}$-gemifloxacin and ${ }^{99 \mathrm{~m}} \mathrm{Tc}-$ sitafloxacin showed a $T / \mathrm{NT}$ ratio higher than 8 (good radiopharmaceutical). This indicates that most radiolabelled antibiotics are not candidate for human studies.

\section{Conclusion}

From the present systematic review it can deduced how difficult it is to find a specific imaging agent to detect bacterial infection and to monitor the effectiveness of antimicrobial therapy. None of the mentioned radiolabelled antibiotics is commercially available because of its minimal or very low specific activity or low specificity for infections versus sterile inflammation or, most frequently for selective specificity to one kind of bacteria only. Despite a large number of original papers have been published, it is difficult to make a head-to-head comparison amongst them. Animal models are often different (mice, rats or rabbits), injected activities and image acquisition times are different, and, most importantly, the number of bacteria used for inducing the infection ranges from $10^{5}$ to
$10^{10}$, being the main limiting factor for a comparison of sensitivity.

Another important problem of antibiotics is the risk of resistance mechanism because bacteria can change very quickly and drug-resistant strains are often the cause of recurring infections. Resistance can also be due from a non specific removal mechanism of antibiotics or sometimes from an enforced efflux by pumps. Furthermore, bacteria do not have a high affinity for antibiotics, nor the binding between the antibiotic and bacteria is specific like the ligand-receptor interaction in mammalian cells. For these reasons the gold standard for bacterial infection imaging has not yet been found. Hopefully in future we will have many radiopharmaceuticals available, tailored for specific pathogens, and clinical conditions thus having the maximum specificity.

It is important also to stress that animal experiments should always be performed before human studies, with several different strains and number of bacteria in order to provide useful information for planning and interpreting human studies.

\section{Complizance with ethics standards}

Funding This study was funded by Nuclear Medicine Discovery (Nu.Me.D.) that supported Dr Filippo Galli and Sveva Auletta with travel grants and by funds from Italian MIUR Ateneo 2012 (Grant $\mathrm{n}^{\circ}$ M-000323-13).

Conflict of interest Alberto Signore and Chiara Lauri are members of the EANM Inflammation-Infection committee. Auletta S declares that she has no conflict of interest. Galli Filippo declares that he has no conflict of interest. Daniela Martinelli declares that she has no conflict of interest. Iolanda Santino declares that she has no conflict of interest.

Ethical approval This article does not contain any studies with human participants or animals performed by any of the authors.

Open Access This article is distributed under the terms of the Creative Commons Attribution 4.0 International License (http://crea tivecommons.org/licenses/by/4.0/), which permits unrestricted use, distribution, and reproduction in any medium, provided you give appropriate credit to the original author(s) and the source, provide a link to the Creative Commons license, and indicate if changes were made.

\section{References}

1. Signore A (2014) The need of shared diagnostic protocols. Q J Nucl Med Mol Imaging 58:1

2. Yurt Lambrecht F (2011) Evaluation of ${ }^{99 \mathrm{~m}} \mathrm{Tc}$-labeled antibiotics for infection detection. Ann Nucl Med 25:1-6. doi:10. 1007/s12149-010-0417-3

3. Oyen WJG, Corstens FHM, Boerman OC (2005) Discriminating infection from sterile inflammation: can radiolabelled antibiotics solve the problem? Eur J Nucl Med Mol Imaging 32:151-152. doi:10.1007/s00259-004-1722-7 
4. Palestro CJ, Glaudemans AWJM, Dierckx RAJO (2013) Multiagent imaging of inflammation and infection with radionuclides. Clin Transl Imaging 1:385-396. doi:10.1007/s40336013-0041-z

5. Shah M, Garg G, Dadachova E (2015) Preclinical testing of radiopharmaceuticals for novel applications in HIV, bacterial and fungal infectious diseases. Q J Nucl Med Mol Imaging 59:317-326

6. Malviya G, Galli F, Sonni I, Signore A (2014) Imaging T-lymphocytes in inflammatory diseases: a nuclear medicine approach. Q J Nucl Med Mol Imaging 58:237-257

7. Signore A, D'Alessandria C, Lazzeri E, Dierckz R (2008) Can we produce an image of bacteria with radiopharmaceuticals? Eur J Nucl Med Mol Imaging 35:1051-1055. doi:10.1007/ s00259-008-0762-9

8. Vinjamuri S, Hall AV, Solanki KK et al (1996) Comparison of ${ }^{99 \mathrm{~m}}$ Tc-1nfecton imaging with radiolabelled white-cell imaging in the evaluation of bacterial infection. Lancet 347:233-235

9. Motaleb MA (2009) Preparation, quality control and stability of ${ }^{99 \mathrm{~m}} \mathrm{Tc}$-sparafloxacin complex, a novel agent for detecting sites of infection. J Label Compd Radiopharm 52:415-418

10. Donlan RM, Costerton JW (2002) Biofilms: survival mechanisms of clinically relevant microorganisms. Clin Microbiol Rev 15:167-193

11. Jacoby GA (2005) Mechanisms of resistance to quinolones. Clin Infect Dis 15(41 Suppl 2):S120-S126

12. Hooper DC (2003) Mechanisms of quinolone resistance. In: Hooper DC, Rubinstein E (eds) Quinolone antimicrobial agents, 3rd edn. American Society for Microbiology, Washington, DC, pp 41-67

13. Brunner M, Langer O, Dobrozemsky G, Müller U, Zeitlinger M, Mitterhauser M, Wadsak W, Dudczak R, Kletter K, Müller M (2004) $\left[{ }^{18}\right.$ F $]$ Ciprofloxacin, a new Positron Emission Tomography tracer for noninvasive assessment of the tissue distribution and pharmacokinetics of ciprofloxacin in humans. Antimicrob Agents Chemother 48:3850-3857. doi:10.1128/AAC.48.10. 3850-3857.2004

14. Bhardwaj N, Bhatnagar A, Singh AK (2005) Development and evaluation of a single vial cold kit for infection imaging: Tc99m Ciprofloxacin. World J Nucl Med 4:244-251

15. Das SS, Britton KE, Solanki KK, Wareham DW (2000) Technetium-99m labelled antimicrobial peptides discriminate between bacterial infections and sterile inflammations. Eur $\mathbf{J}$ Nucl Med 27:1865-1868. doi:10.1007/s002590000378

16. Oh SJ, Ryu JS, Shin JW, Yoon EJ, Ha HJ, Cheon JH, Lee HK (2002) Synthesis of ${ }^{99 \mathrm{~m}} \mathrm{Tc}$-ciprofloxacin by different methods and its biodistribution. Appl Radiat Isot 57:193-200

17. Doroudi A, Erfani M, Kooshki F, Saadati SF, Ahmadi F, Kiasat A, Khodayar MJ, Etessami B, Meghdadi H (2015) Efficacy of ${ }^{99 \mathrm{~m}} \mathrm{Tc}$-Ciprofloxacin and ${ }^{67} \mathrm{Ga}$-Citrate scintigraphy to discriminate infection foci induced by Staphylococcus Aureus from sterile inflammation induced by Carrageenan in rat. Iran J Nucl Med 23:96-102

18. Satpati D, Arjun C, Krishnamohan R, Samuel G, Banerjee S $(2015){ }^{68} \mathrm{Ga}$-labeled ciprofloxacin conjugates as radiotracers for targeting bacterial infection. Chem Biol Drug Des. doi:10.1111/ cbdd.12701

19. Aungurarat A, Ngamprayad T, Dangprasert M, Phumkem S, Jowanaridhi B (2015) ${ }^{99 \mathrm{~m}}$ Tc-ciprofloxacin for diagnosis of bacterial infection. J Physics. doi:10.1088/1742-6596/611/1/ 012029

20. Zhang H, Jiang N, Zhu L (2009) Experimental studies on imaging of infected site with ${ }^{99 \mathrm{~m}} \mathrm{Tc}$-labeled ciprofloxacin in mice. Chin Med J 122:1907-1909

21. Dahiya S, Chuttani K, Khar RK, Saluja D, Mishra AK, Chopra M (2009) Synthesis and evaluation of ciprofloxacin derivatives as diagnostic tools for bacterial infection by Staphylococcus Aureus. Metallomics 1:409-417

22. Mirshojaei SF, Erfani M, Sadat-Ebrahimi SE, Talebi MH, Abbasi FHH (2010) Freeze-dried cold kit for preparation of ${ }^{99 \mathrm{~m}} \mathrm{Tc}$-ciprofloxacin as an infection imaging agent. Iran J Nucl Med 18:45-51

23. Sarda L, Saleh-Mghir A, Peker C, Meulemans A, Crémieux AC, Le Guludec D (2002) Evaluation of ${ }^{99 m}$ Tc-ciprofloxacin scintigraphy in a rabbit model of Staphylococcus Aureus prosthetic joint infection. J Nucl Med 43:239-245

24. Wang JH, Sun GF, Zhang J, Shao CW, Zuo CJ, Hao J, Zheng JM, Feng XY (2013) Infective severe acute pancreatitis: a comparison of ${ }^{99 \mathrm{~m}} \mathrm{Tc}$-ciprofloxacin scintigraphy and computed tomography. World J Gastroenterol 19:4897-4906

25. Alexander K, Drost WT, Mattoon JS, Anderson DE (2005) ${ }^{99 \mathrm{~m}} \mathrm{Tc}$-ciprofloxacin in imaging of clinical infections in camelids and a goat. Vet Radiol Ultrasound 46:340-347

26. Peremans K, De Winter F, Janssens L, Dumont F, Van Bree H, Dierckx R (2002) An infected hip prosthesis in a dog diagnosed with a ${ }^{99 m}$ Tc-ciprofloxacin (Infecton) scan. Vet Radiol Ultrasound 43:178-182

27. Langer O, Brunner $M$, Zeitlinger $M$, Ziegler S, Müller U, Dobrozemsky G, Lackner E, Joukhadar C, Mitterhauser M, Wadsak W, Minar E, Dudczak R, Kletter K, Müller M (2005) In vitro and in vivo evaluation of $\left[{ }^{18} \mathrm{~F}\right]$ ciprofloxacin for the imaging of bacterial infections with PET. Eur J Nucl Med Mol Imaging 32:143-150. doi:10.1007/s00259-004-1646-2

28. Britton KE, Vinjamuri S, Hall AV, Solanki K, Siraj QH, Bomanji J, Das S (1997) Clinical evaluation of technetium-99 m infecton for the localisation of bacterial infection. Eur J Nucl Med 24:553-556

29. Das SS, Britton KE (2003) Bacterial infection imaging. World J Nucl Med 2:173-179

30. De Winter F, Van de Wiele C, Dumont F, Van Durme J, Solanki K, Britton K, Slegers G, Dierckx RA, Thierens H (2001) Biodistribution and dosimetry of ${ }^{99 \mathrm{~m}} \mathrm{Tc}$-ciprofloxacin, a promising agent for the diagnosis of bacterial infection. Eur $\mathbf{J}$ Nucl Med 28:570-574. doi:10.1007/s002590100488

31. Falagas ME, Valotassiou VJ, Papadouli D, Papadopoulos A, Malamitsi J (2006) ${ }^{99 \mathrm{~m}}$ Technetium-ciprofloxacin scintigraphy for the evaluation of spinal infections. Clin Orthop Rel Res 444:34-37

32. Hall AV, Solanki KK, Vinjamuri S, Britton KE, Das SS (1998) Evaluation of the efficacy of ${ }^{99 \mathrm{~m}} \mathrm{Tc}$-Infecton, a novel agent for detecting sites of infection. J Clin Pathol 51:215-219

33. Britton KE, Wareham DW, Das SS, Solanki KK, Amaral K, Bhatnagar A, Katamihardja AHS, Malamitsi J, Moustafa HM, Soroa VE, Sundram FX, Padhy AK (2002) Imaging bacterial infection with ${ }^{99 \mathrm{~m}} \mathrm{Tc}$-ciprofloxacin (Infecton). J Clin Pathol 55:817-823

34. Larikka MJ, Ahonen $A K$, Niemelä $O$, Junila JA, Hämäläinen MM, Britton K, Syrjälä HP (2002) Comparison of ${ }^{99 m} \mathrm{Tc}$ ciprofloxacin, ${ }^{99 \mathrm{~m}} \mathrm{Tc}$ white blood cell and three-phase bone imaging in the diagnosis of hip prosthesis infections: improved diagnostic accuracy with extended imaging time. Nucl Med Comm 23:655-661

35. Lee M, Yoon M, Hwang KH, Choe W (2010) Tc-99m ciprofloxacin SPECT of pulmonary tuberculosis. Nucl Med Mol Imaging 44:116-122. doi:10.1007/s13139-010-0021-4

36. Artiko V, Davidović B, Nikolić N, Petrović M, Petrović N, Vlajković M, Peško P, Knežević S, Dukić V, Stefanović B, Tulić C, Popović N, Obradović V (2005) Detection of gastrointestinal and abdominal infections by ${ }^{99 \mathrm{~m}} \mathrm{Tc}$-ciprofloxacin. Hepato-gastroenterol 52:491-495

37. Obradović V, Artiko V, Petrović N, Davidović B, Nikolić N, Vucetic C, Sobic-Saranovic D, Todorovic-Tirnanic M, 
Vlajković M (2003) Preliminary results of imaging orthopaedic infection with Tc-99m ciprofloxacin using a newly developed simple labelling kit. World J Nucl Med 2:269-274

38. Amaral H, Morales B, Pruzzo R, Britton K (1999) Cold-hot mismatch between Tc-99m HMPAO-labeled leukocytes and Tc-99m ciprofloxacin in axial skeleton infections: a report of three cases. Clin Nucl Med 24:855-858

39. Malamitsi J, Papadopoulos A, Vezyrgianni A, Dalianis K, Boutsikou M, Giamarellou H (2011) The value of successive Infecton scans in assessing the presence of chronic bone and joint infection and in predicting its evolution after treatment and after a prolonged follow-up. Nucl Med Commun 32:1060-1069

40. Choe Y, Choe W, Lee K, Ahn S, Kim K, Cho YU, Choi SK, Hur Y, Kim S, Hong K, Shin S, Kim K, Woo Z (2007) Tc-99m ciprofloxacin imaging in acute cholecystitis. World J Gastroenterol 13:3249-3252

41. Fuster D, Soriano A, Garcia S, Piera C, Suades J, Rodriguez D, Martinez JC, Mensa J, Campos F, Pons F (2011) Usefulness of ${ }^{99 \mathrm{~m}} \mathrm{Tc}$-ciprofloxacin scintigraphy in the diagnosis of prosthetic joint infections. Nucl Med Commun 32:44-51

42. Larikka MJ, Ahonen AK, Niemelä O, Puronto O, Junila JA, Hämäläinen MM, Britton K, Syrjälä HP (2002) ${ }^{99 \mathrm{~m}}$ Tc-ciprofloxacin (Infecton) imaging in the diagnosis of knee prosthesis infections. Nucl Med Commun 23:167-170

43. Sharma R, Mondal A, Sharma M, Popli M, Chopra MK, Sawroop K, Kashyap R (2001) Tc-99m infecton scan in possible pelvic inflammatory disease. Clin Nucl Med 26:208-211

44. Sharma R, Tewari KN, Bhatnagar A, Mondal A, Mishra AK, Singh AK, Chopra MK, Rawat H, Kashyap R, Tripathi RP (2007) Tc-99m ciprofloxacin scans for detection of tubercular bone infection. Clin Nucl Med 32:367-370

45. Singh B, Sunil HV, Sharma S, Prasad V, Kashyap R, Bhattacharya A, Mittal BR, Taneja A, Rai R, Goni VG, Aggarwal S, Gill SS, Bhatnagar A, Singh AK (2008) Efficacy of indigenously developed single vial kit preparation of ${ }^{99 \mathrm{~m}} \mathrm{Tc}$-ciprofloxacin in the detection of bacterial infection: an Indian experience. Nucl Med Comm 29:1123-1129

46. Sonmezoglu K, Sonmezoglu M, Halac M, Akgün I, Türkmen C, Önsel C, Kanmaz B, Solanki K, Britton KE, Uslu I (2001) Usefulness of ${ }^{99 \mathrm{~m}} \mathrm{Tc}$-ciprofloxacin (Infecton) scan in diagnosis of chronic orthopedic infections: comparative study with ${ }^{99 \mathrm{~m}} \mathrm{Tc}$ HMPAO leukocyte scintigraphy. J Nucl Med 42:567-574

47. Malamitsi J, Giamarellou H, Kanellakopoulou K, Dounis E, Grecka V, Christakopoulos J, Koratzanis G, Antoniadou A, Panoutsopoulos G, Batsakis C, Proukakis C (2003) Infecton: a ${ }^{99 \mathrm{~m}} \mathrm{Tc}$-ciprofloxacin radiopharmaceutical for the detection of bone infection. Clin Microbiol Infect 9:101-109

48. Dutta P, Bhansali A, Mittal BR, Singh B, Masoodi SR (2006) Instant ${ }^{99 \mathrm{~m}} \mathrm{Tc}$-ciprofloxacin scintigraphy for the diagnosis of osteomyelitis in the diabetic foot. Foot Ankle Int 27:716-722

49. Gallowitsch HJ, Heinisch M, Mikosch P, Kresnik E, Kumnig G, Gomez I, Lind P (2002) Tc-99m ciprofloxacin in clinically selected patients for peripheral osteomyelitis, spondylodiscitis and fever of unknown origin-preliminary results. Nuklearmedizin 41:30-36

50. Bhardwaj V, Agrawal M, Suri T, Sural S, Kashyap R, Dhal A (2011) Evaluation of adequacy of short-course chemotherapy for extraspinal osteoarticular tuberculosis using ${ }^{99 \mathrm{~m}} \mathrm{Tc}$ ciprofloxacin scan. Int Orthop 35:1869-1874

51. Dumarey N, Blocklet D, Appelboom T, Tant L, Schoutens A (2002) Infecton is not specific for bacterial osteo-articular infective pathology. Eur J Nucl Med 29:530-535. doi:10.1007/ s00259-001-0749-2

52. De Winter F, Gemmel F, Van Laere K, De Winter O, Poffijn B, Dierckx RA, Van de Wiele C (2004) ${ }^{99 \mathrm{~m}}$ Tc-Ciprofloxacin planar and tomographic imaging for the diagnosis of infection in the postoperative spine: experience in 48 patients. Eur $\mathrm{J}$ Nucl Med Mol Imaging 31:233-239. doi:10.1007/s00259-003-1349-0

53. Sarda L, Crémieux AC, Lebellec Y, Meulemans A, Lebtahi R, Hayem G, Génin R, Delahaye N, Huten D, Le Guludec D (2003) Inability of ${ }^{99 \mathrm{~m}} \mathrm{Tc}$-ciprofloxacin scintigraphy to discriminate between septic and sterile osteoarticular diseases. J Nucl Med 44:920-926

54. Pucar D, Jancović Z, Dugonjić S, Popović Z (2009) Estimation of ${ }^{99} \mathrm{~m}$ Tc-ciprofloxacin accumulation indexes in bone and joint bacterial infections. Vojnosanit Pregl 66:395-398

55. Gemmel F, De Winter F, Van Laere K, Vogelaers D, Uyttendaele D, Dierckx RA (2004) ${ }^{99 \mathrm{~m}} \mathrm{Tc}$ ciprofloxacin imaging for the diagnosis of infection in the postoperative spine. Nucl Med Comm 25:277-283

56. Appelboom T, Emery P, Tant L, Dumarey N, Schoutens A (2003) Evaluation of technetium-99m-ciprofloxacin (Infecton) for detecting sites of inflammation in arthritis. Rheumatol 42:1179-1182

57. Zhang J, Guo H, Zhang S, Lin Y, Wang X (2008) Synthesis and biodistribution of a novel ${ }^{99 \mathrm{~m}} \mathrm{TcN}$ complex of ciprofloxacin dithiocarbamate as a potential agent for infection imaging. Bioorg Med Chem Lett 18:5168-5170

58. Zhang J, Zhang S, Guo H, Wang X (2010) Synthesis and biological evaluation of a novel ${ }^{99 \mathrm{~m}} \mathrm{Tc}(\mathrm{CO})_{3}$ complex of ciprofloxacin dithiocarbamate as a potential agent to target infection. Bioorg Med Chem Lett 20:3781-3784

59. Ball P, Tillotson G (1995) Tolerability of fluoroquinolone antibiotics. Past, present and future. Drug Saf 13:343-358

60. King DE, Malone R, Lilley SH (2000) New classification and update on the quinolone antibiotics. Am Fam Physician 61:2741-2748

61. El-Ghany EA, El-Kolaly MT, Amine AM, El-Sayed AS, AbdelGelil F (2005) Synthesis of ${ }^{99 m}$ Tc-pefloxacin: a new targeting agent for infectious foci. J Radioanal Nucl Chem 266:131-139

62. Motaleb MA (2007) Preparation and biodistribution of ${ }^{99 \mathrm{~m}} \mathrm{Tc}-$ lomefloxacin and ${ }^{99 \mathrm{~m}} \mathrm{Tc}$-ofloxacin complexes. J Radioanal Nucl Chem 272:95-99. doi:10.1007/s10967-006-6786-3

63. Erfani M, Doroudi A, Hadisi L, Andishmand A, Mirshojaei SF, Shafiei M (2013) ${ }^{99 \mathrm{~m}}$ Tc-tricabonyl labeling of ofloxacin and its biological evaluation in Staphylococcus aureus as an infection imaging agent. J Label Compd Radiopharm 56:627-631. doi:10. 1002/jlcr.3093

64. Siaens RH, Rennen HJ, Boerman OC, Dierckx R, Slegers G (2004) Synthesis and comparison of ${ }^{99 \mathrm{~m}} \mathrm{Tc}$-enrofloxacin and ${ }^{99 \mathrm{~m}}$ Tc-ciprofloxacin. J Nucl Med 45:2088-2094

65. Shahzad S, Qadir MA, Rasheed R, Ahmad A, Shafiq MI, Ahmed M, Noreen S, Ali A, Shahzadi SK, Javed M (2016) A new method for synthesis of ${ }^{99 \mathrm{~m}} \mathrm{Tc}$-enorfloxacin: an infection imaging agent. Lat Am J Pharm 35:259-264

66. Ibrahim IT, Motaleb MA, Attalah KM (2010) Synthesis and biological distribution of ${ }^{99 \mathrm{~m}} \mathrm{Tc}-$ norfloxacin complex, a novel agent for detecting sites of infection. J Radioanal Nucl Chem 285:431-436. doi:10.1007/s10967-010-0607-4

67. Sazonova SI, Lishmanov YB, Varlamova NV, Skuridin VS, Ilushenkova YN, Karpova MR, Nesterov YA (2015) Synthesis and experimental study of norfloxacin labeled with technecium$99 \mathrm{~m}$ as a potential agent for infection imaging. Iran J Nucl Med 23:73-81

68. Zhang S, Zhang W, Wang Y, Jin Z, Wang X, Zhang J, Zhang Y (2011) Synthesis and biodistribution of a novel ${ }^{99 \mathrm{~m}} \mathrm{TcN}$ complex of norfloxacin dithiocarbamate as a potential agent for bacterial infection imaging. Bioconjugate Chem 22:369-375

69. Andriole VT (2005) The quinolones: past, present and future. Clin Infect Dis 41:113-119. doi:10.1086/428051

70. Shahzad S, Qadir MA, Rasheed R, Anwar S, Ahmed M (2015) In vivo studies ${ }^{99} \mathrm{~m}$ Tc-levofloxacin freeze dried kits in 
Salmonella typhi, Pseudoman aeruginosa, and Escherichia coli. Lat Am J Pharm 34:760-765

71. Motaleb MA, Ayoub SM (2013) Preparation, quality control, and biodistribution of ${ }^{99 \mathrm{~m}} \mathrm{Tc}$-rufloxacin complex as a model for detecting sites of infection. Radiochem 55:610-614. doi:10. 1134/S1066362213060088

72. Fischman AJ, Livni E, Babich J, Alpert NM, Liu Y, Thom E, Cleeland R, Prosser BL, Callahan RJ, Correia JA, Strauss HW, Rubin RH (1992) Pharmacokinetics of ${ }^{18} \mathrm{~F}_{\text {-labeled fleroxacin in }}$ rabbits with Escherichia coli infections, studied with positron emission tomography. Antimicrob Agents Chem 36:2286-2292

73. Mather R, Karenchak LM, Romanowski EG, Kowalski RP (2002) Fourth generation fluoroquinolones: new weapons in the arsenal of ophthalmic antibiotics. Am J Oph 133:463-466

74. Qaiser SS, Khan AU, Khan MR (2010) Synthesis, biodistribution and evaluation of ${ }^{99 \mathrm{~m}} \mathrm{Tc}$-sitafloxacin kit: a novel infection imaging agent. J Radioanal Nucl Chem 284:189-193. doi:10. 1007/s10967-010-0470-3

75. Qaiser SS, Khan AU, Khan MR (2011) Radiosynthesis and biological evaluation of ${ }^{99 \mathrm{~m}} \mathrm{TcN}$-sitafloxacin dithiocarbamate as a potential radiotracer for Staphylococcus aureus infection. J Radioanal Nucl Chem 287:827-832. doi:10.1007/s10967-0100833-9

76. Chattopadhyay S, Saha Das S, Chandra S, De K, Mishra M, Sarkar BR, Sinha S, Ganguly S (2010) Synthesis and evaluation of ${ }^{99 \mathrm{~m}} \mathrm{Tc}$-moxifloxacin, a potential infection specific imaging agent. Appl Radia Isot 68:314-316. doi:10.1016/j.apradiso. 2009.10.030

77. Qaiser SS, Khan MR (2011) Radiolabeling of gemifloxacin with technetium-99m and biological evaluation in artificially Streptococcus pneumoniae infected rats. J Radioanal Nucl Chem 288:307-312. doi:10.1007/s10967-010-0916-7

78. Shahzad S, Qadir MA, Rasheed R, Ahmed M (2015) Synthesis of ${ }^{99 \mathrm{~m}}$ Tc-gemifloxacin freeze dried kits and their biodistribution in Salmonella typhi, Pseudomonas aeruginosa and Klebsiella pneumonia. Arab J Chem. doi:10.1016/j.arabjc.2015.10.002

79. Moustapha ME, Motaleb MA, Shweeta H, Farouk M (2016) Synthesis and biological evaluation of technetium-sarafloxacin complex for infection imaging. J Radioanal Nucl Chem 307:699-705. doi:10.1007/s10967-015-4188-0

80. El-Tawoosy M (2013) Preparation and biological distribution of ${ }^{99 \mathrm{~m}}$ Tc-cefazolin complex, a novel agent for detecting sites of infection. J Radioanal Nucl Chem 298:1215-1220

81. YurtLambrecht F, Yilmaz O, Unak P, Seyitoglu B, Durkan K, Baskan $\mathrm{H}$ (2008) Evaluation of ${ }^{99 \mathrm{~m}} \mathrm{Tc}$ cefuroxime axetil for imaging of inflammation. J Radioanal Nucl Chem 277:491-494. doi:10.1007/s10967-007-7111-5

82. Chattopadhyay S, Ghosh M, Sett S, Das MK, Chandra S, De K, Mishra M, Sinha S, Sarkar BR, Ganguly S (2012) Preparation and evaluation of $99 \mathrm{mTc}$-cefuroxime, a potential infection specific imaging agent: a reliable thin layer chromatographic system to delineate impurities from the $99 \mathrm{mTc}$-antibiotic. Appl Radia Isot 70:2384-2387

83. Klein NC, Cunha BA (1995) Third-generation cephalosporins. Med Clin North Am 79:705-719

84. Gomes Barreto V, Rabiller G, Iglesias F, Soroa V, Tubau F, Roca M, Martìn-Comìn J (2005) Gammagrafía con ${ }^{99 m}$ Tc-ceftizoxima en ratas normales y en ratas con absceso inducido. Rev Esp Med Nucl 24:312-318

85. Costa PHN, Diniz SOF, Cardoso VN, Tarabal B, Takenaka I, Braga O, Vidigal PVT, Gelape CL, Araujo ID (2015) Scintigraphic imaging with technetium-99 M-labelled ceftizoxime is a reliable technique for the diagnosis of deep sternal wound infection in rats. Acta Cirurgica Brasileira 30:632-638

86. Teixeira LEM, Soares GG, Teixeira HC, Takenaka IKTM, Diniz SOF, de Andrade MAP, Cardoso VN, de Araujo ID (2015)
Efficacy of ${ }^{99 \mathrm{~m}} \mathrm{Tc}$-labeled ceftizoxime in the diagnosis of subclinical infections associated with titanium implants in rats. Surg Inf 16:352-357

87. Mirshojaei SF, Gandomkar M, Najafi R, Sadat Ebrahimi SE, Babaei MH, Shafiei A, Talebi MH (2011) Radio labeling, quality control and biodistribution of ${ }^{99 \mathrm{~m}} \mathrm{Tc}$-cefotaxime as an infection imaging agent. J Radioanal Nucl Chem 287:21-25. doi:10.1007/s10967-010-0826-8

88. Ilem-Ozdemir D, Asikoglu M, Ozkilic H, Yilmaz F, HosgorLimoncu M, Ayhan S (2016) Gamma scintigraphy and biodistribution of ${ }^{99 \mathrm{~m}} \mathrm{Tc}$-cefotaxime sodium in preclinical models of bacterial infection and sterile inflammation. J Label Compd Radiopharm 59:109-116

89. Mostafa M, Motaleb MA, Sakr TM (2010) Labeling of ceftriaxone for infective inflammation imaging using ${ }^{99 \mathrm{~m}} \mathrm{Tc}$ eluted from ${ }^{99} \mathrm{Mo} /{ }^{99 \mathrm{~m}} \mathrm{Tc}$ generator based on zirconium molybdate. Appl Radiat Isot 68:1959-1963. doi:10.1016/j.apradiso.2010.04. 031

90. Kaul A, Hazari PP, Rawat H, Singh B, Kalawat TC, Sharma S, Babbar AK, Mishra AK (2012) Preliminary evaluation of technetium-99m-labeled ceftriaxone: infection imaging agent for the clinical diagnosis of orthopedic infection. Int J Infect Dis 17(4):e263-e270. doi:10.1016/j.ijid.2012.10.011

91. Fazli A, Salouti M, Mazidi M (2013) ${ }^{99 \mathrm{~m}}$ Tc-ceftriaxone, as a targeting radiopharmaceutical for scintigraphic imaging of infectious foci due to Staphylococcus aureus in mouse model. J Radioanal Nucl Chem 298:1227-1233. doi:10.1007/s10967013-2523-x

92. Sohaib M, Khurshid Z, Roohi S (2014) Labelling of ceftriaxone with ${ }^{99 \mathrm{~m}} \mathrm{Tc}$ and its bio-evaluation as an infection imaging agent. J Label Compd Radiopharm 57:652-657

93. Mirshojaei SF, Erfani M, Shafiei M (2013) Evaluation of ${ }^{99 \mathrm{~m}} \mathrm{Tc}-$ ceftazidime as bacterial infection imaging agent. J Radioanal Nucl Chem 298:19-24. doi:10.1007/s10967-013-2418-x

94. Motaleb MA (2007) Preparation of ${ }^{99 \mathrm{~m}}$ Tc-cefoperazone complex, a novel agent for detecting sites of infection. J Radioanal Nucl Chem 272:167-171. doi:10.1007/s10967-006-6754-y

95. Motaleb MA (2011) Study on the preparation and biological evaluation of ${ }^{99 \mathrm{~m}} \mathrm{Tc}$-gatifloxacin and ${ }^{99 \mathrm{~m}} \mathrm{Tc}$-cefepime complexes. J Radioanal Nucl Chem 289:57-65. doi:10.1007/s10967011-1058-2

96. Hunt R, Microbiology and immunology online, University of South Carolina School of Medicine

97. Ankrah AO, van der Werf TS, de Vries EFJ, Dierckx RAJO, Sathegke MM, Glaudemans AWJM (2016) PET/CT imaging of mycobacterium tuberculosis infection. Clin Transl Imaging. 4:131-144. doi:10.1007/s40336-016-0164-0

98. Qaiser SS, Khan AU, Khan MR (2010) Radiosynthesis and biodistribution of ${ }^{99 \mathrm{~m}} \mathrm{Tc}$-rifampicin: a novel radiotracer for in vivo infection imaging. Appl Radiat Isot 68:2255-2260. doi:10.1016/j.apradiso.2010.05.014

99. Komp Lindgren P, Klockars O, Malmberg C, Cars O (2015) Pharmacodynamic studies of nitrofurantoin against common uropathogens. J Antimicrob Chemother 70:1076-1082. doi:10. 1093/jac/dku494

100. Qaiser SS, Khan AU, Khan MR (2011) Radiosynthesis of ${ }^{99 m}$ Tcnitrofurantoin a novel radiotracer for in vivo imaging of Escherichia Coli infection. J Radioanal Nucl Chem 287:417-422. doi:10.1007/s10967-010-0697-z

101. Silver LL (2003) Novel inhibitors of bacterial cell wall synthesis. Curr Opin Microbiol 6:431-438. doi:10.1016/j.mib.2003. 08.004

102. Andes D, Craig WA (1998) In vivo activities of amoxicillin and amoxicillin-clavulanate against Streptococcus Pneumoniae: application to breakpoint determinations. Antimicrob Agents Chemother 42:2375-2379 
103. Shahzadi SK, Qadir MA, Shahzad S, Javed M (2015) ${ }^{99 \mathrm{~m}} \mathrm{Tc}-$ amoxicillin: a novel radiopharmaceutical for infection imaging. Arabian J Chem. doi:10.1016/j.arabjc.2015.04.003

104. Atherton FR, Hall MJ, Hassal CH, Lambert RW, Lloyd WJ, Ringrose PS (1979) Phosphonopeptides as antibacterial agents: mechanism of action of alaphosphin. Antimicrob Agents Chemother 15:696-705

105. Tsopelas C, Penglis S, Ruszkiewicz A, Bartholomeusz FDL (2003) ${ }^{99 \mathrm{~m}}$ Tc-alafosfalin: an antibiotic peptide infection imaging agent. Nucl Med Biol 30:169-175

106. Martìnez ME, Kiyono Y, Noriki S, Inai K, Mandap KS et al (2011) New radiosynthesis of 2-deoxy-2-[ $\left.{ }^{18} \mathrm{~F}\right]$ fluoroacetamidoD-glucopyranose and its evaluation as a bacterial infections imaging agent. Nucl Med Biol 38:807-817. doi:10.1016/j.nuc medbio.2011.02.006

107. Neu HC, Gootz TD (1996) Antimicrobial chemotherapy. In: Baron S (ed) Medical microbiology, 4th edn, chapter 11, Galveston (TX): University of Texas Medical Branch at Galveston

108. Roohi S, Mushtaq A, Malik SA (2005) Synthesis and biodistribution of ${ }^{99 \mathrm{~m}} \mathrm{Tc}$-vancomycin in a model of bacterial infection. Radiochim Acta 93:415-418

109. Lowy F (2009) Protein synthesis inhibitors. Division of Infectious Diseases, University of Columbia

110. Roohi S, Mushtaq A, Jehangir M, Malik SA (2006) Synthesis, quality control and biodistribution of ${ }^{99 \mathrm{~m}} \mathrm{Tc}$-kanamycin. J Radioanal Nucl Chem 262:561-566

111. İlem-Özdemir D, Asikoglu M, Ozkilic H et al (2014) 99mTcdoxycycline hyclate: a new radiolabeled antibiotic for bacterial infection imaging. J Label Compd Radiopharm 57:36-41. doi: $10.1002 / \mathrm{jlcr} .3135$

112. Abdel-Ghaney IY, Sanad MH (2013) Synthesis of ${ }^{99 m}$ Tc- erythromycin complex as a model for infection sites imaging. Radiochem 55:418-422. doi:10.1134/S1066362213040139

113. Hina S, Rajoka MI, Savage PB, Roohi S, Bokhari TH (2015) Labeling, quality control and biological evaluation of ${ }^{99 \mathrm{~m}} \mathrm{Tc}$ vibramycin for infection sites imaging. Bulg Chem Comm 47:747-754

114. Yang ZY, Wang L, Tang X (2009) Determination of azithromycin by ion-pair HPLC with UV detection. J Pharm Biomed Anal 49:811-815. doi:10.1016/j.jpba.2008.12.018

115. Sanad MH (2013) Labelling and biological evaluation of ${ }^{99 m} \mathrm{Tc}-$ azithromycin for infective inflammation diagnosis. Radiochem 55:539-544. doi:10.1134/S1066362213050159

116. Borai EH, Sanad MH, Fouzy ASM (2016) Optimized Chromatographic Separation and Biological Evaluation of ${ }^{99 m} \mathrm{Tc}$ -
Clarithromycin for Infective Inflammation Diagnosis. Radiochem 58:84-91

117. Morar M, Bhullar K, Hughes DW, Junop M, Wright GD (2009) Structure and mechanism of the lincosamide antibiotic adenylyltransferase linB. Structure 17:1649-1659. doi:10.1016/j.str. 2009.10.013

118. Hina S, Rajoka MI, Roohi S, Haque A, Qasim M (2014) Preparation, biodistribution, and scintigraphic evaluation of ${ }^{99} \mathrm{~m}$ Tc-clindamycin: an infection imaging agent. Appl Biochem Biotechnol 174:1420-1433. doi:10.1007/s12010-014-1075-Z

119. de la Torre-Iglesias PM, Garcìa-Rodriguez JJ, Torrado G, Torrado S, Torrado-Santiago $\mathrm{S}$, Bolàs-Fernàndez $\mathrm{S}$ (2014) Enhanced bioavailability and anthelmintic efficacy of mebendazole in redispersible microparticles with low-substituted hydroxypropylcellulose. Drug Des Devel Ther 18:1467-1479. doi:10.2147/DDDT.S65561

120. Inceboz T, Yurt Lambrecht F, Yilmaz O et al (2012) Technetium-99m labeled mebendazole and biodistribution in experimentally Trichinella spiralis-infected rats. Med Chem Res 21:804-809. doi:10.1007/s00044-011-9590-8

121. Ning X, Lee S, Wang Z, Kim D, Stubblefield B, Gilbert E, Murthy N (2011) Maltodextrin-based imaging probes detect bacteria in vivo with high sensitivity and specificity. Nat Mat 10:602-607. doi:10.1038/NMAT3074

122. Gowrishankar G, Namavari M, Jouannot EB, Hoehne A, Reeves R, Hardy J, Gambhir SS (2014) Investigation of 6- $\left[{ }^{18} \mathrm{~F}\right]$-fluoromaltose as a novel PET tracer for imaging bacterial infection. PLoS ONE 9(9):e107951

123. Petrik M, Franssen GM, Haas H, Laverman P, Hörtnagl C, Schrettl M, Helbok A, Lass-Flörl C, Decristoforo C (2012) Preclinical evaluation of two ${ }^{68} \mathrm{Ga}$-siderophores as potential radiopharmaceuticals for Aspergillus Fumigatus infection imaging. Eur J Nucl Med Mol Imaging 39:1175-1183. doi:10. 1007/s00259-012-2110-3

124. Petrik M, Haas H, Laverman P, Schrettl M, Franssen GM, Blatzer M, Decristoforo C (2014) ${ }^{68} \mathrm{Ga}$-triacetylfusarinine $\mathrm{C}$ and ${ }^{68} \mathrm{Ga}$-ferrioxamine $\mathrm{E}$ for Aspergillus infection imaging: uptake specificity in various microorganisms. Mol Imaging Biol 16:102-108. doi:10.1007/s11307-013-0654-7

125. Motaleb MA, Alabdullah ES, Zaghary WA (2011) Synthesis, radiochemical and biological characteristics of ${ }^{99 \mathrm{~m}} \mathrm{Tc}-8$-hydroxy-7-substituted quinoline complex: a novel agent for infection imaging. J Radioanal Nucl Chem 287:61-67. doi:10. 1007/s10967-010-0818-8 